This draft: 17 February 2016

\title{
Household Finances, Income Shocks and Family Separation in Britain
}

\author{
Sarah Bridges ${ }^{\mathrm{a}}$ and Richard Disney ${ }^{\mathrm{b} *}$ \\ ${ }^{a}$ School of Economics, University of Nottingham, Nottingham, NG7 2RD, UK \\ ${ }^{b}$ Institute for Fiscal Studies, Ridgmount Street, London WC1E 7AE, University College, \\ London, and University of Sussex, UK
}

\begin{abstract}
We examine the effect of household financial indebtedness on the incidence of partnership dissolution using a large survey of families with children in Britain. We use detailed data on household finances to provide a robust statistical analysis of the relationship between indebtedness and partnership dissolution and to avoid the potential simultaneity of financial and psychological health responses that arise when using self-reported data on the extent of household 'financial problems'. We examine whether the data provides any support for the 'economic' models of divorce and separation developed by Gary Becker and his colleagues.
\end{abstract}

Key words: debt, separation, household finances

JEL Classification: J12; D12

\section{Acknowledgements}

Our thanks to the University of Nottingham for funding this work, and to the National Centre for Social Research, and the Department for Work and Pensions for provision of data. The Families and Children Survey has been accessed through the ESRC Data Archive at the University of Essex. The suggestions of two referees and the editor on a previous draft are gratefully acknowledged.

* Corresponding author: Dr Sarah Bridges, School of Economics, Sir Clive Granger Building, University of Nottingham, Nottingham, NG7 2RD. Tel: + 44(0)1158 466715 email: sarah.bridges@nottingham.ac.uk 


\section{Introduction}

This paper investigates the effect that financial stress, perhaps induced by adverse changes to the economic position of the household, has on the probability of partnership dissolution in Britain. It uses data from a large random sample of couples with children, including unmarried cohabiting couples, over the period 2001-2008. Despite a growing literature which examines the effect of changing economic circumstances on family well-being (such as Wildman, 2003; Ferrie et al, 2003 and Bridges and Disney, 2010), the impact of financial stress on other aspects of family life, notably the stability of partnerships between couples, has rarely been empirically investigated, let alone with recent data. In particular, few empirical studies have looked specifically at the impact of household indebtedness and periods of financial stress on partnership instability. A likely reason for this omission, especially in Britain, is the absence of suitable data sets with precise measures of household indebtedness. Such an analysis seems overdue given the financial position of many families in Britain. Not only has real household disposable income fallen in recent years (ONS, 2011), but household indebtedness in the UK remains among the highest in the European Union (OECD, 2012). ${ }^{1}$

We address this gap in the empirical literature using data from the Families and Children Survey (FACS), a rich but under-utilised panel data set. The FACS is a unique data set in Britain insofar as it contains precise indicators of household financial stress in addition to general changes in household economic circumstances. The survey asks both qualitative and quantitative questions on financial hardship in each wave, together with questions on the extent and nature of credit and borrowing arrangements and measures of 'over-indebtedness'

\footnotetext{
${ }^{1}$ The Office for Budget Responsibility (OBR) predicts that household debt will be $£ 2,113$ bn by the end of 2015 . According to Credit Action (a debt advice charity), this would increase the average household debt (including mortgages) from $£ 57,635$ in 2011 to $£ 83,849$ per household in 2015.
} 
such as the level of arrears on debt. ${ }^{2}$ These questions are not available in other surveys examining family behaviour. ${ }^{3}$

We estimate the hazard of separation (i.e. of divorce/partnership dissolution) using a discrete-time proportional hazard model, where survival time is the duration of the partnership. ${ }^{4}$ We examine whether the underlying stability of the partnership is affected by household indebtedness, and whether changes ('shocks') to the financial position of the household such as increases or decreases in the level of over-indebtedness, and job gain and loss, influence the stability of the union.

We find that over-indebtedness, captured by the number of debts (including household bills) when the household is in arrears, has a positive effect on the likelihood of separation. However, the analysis also establishes that any changes, whether positive or negative, to the household's economic position may affect the probability of partnership dissolution. These findings persist after controlling for life cycle effects and unobserved heterogeneity. For example, a reduction in the level of over-indebtedness and an increase in labour market participation increase the incidence of separation, along with the expected effect of adverse shocks or 'stress' variables such as worsening over-indebtedness. Insofar as these changes are unanticipated by one or other partner, the results are consistent with Becker et al.'s (1977) model of partnership dissolution.

One basic problem in establishing causality from over-indebtedness to partnership dissolution is that shocks to households may simultaneously both increase over-indebtedness and the likelihood of separation. For example, becoming unemployed may lead to behaviour

\footnotetext{
${ }^{2}$ Although there is no agreed single measure of over-indebtedness, in line with other studies we use whether the household has arrears on consumer debt and on other household bills as our primary indicator of overindebtedness (see Bridges and Disney, 2004, and Kempson et al., 2004).

3 The British Household Panel Survey asks questions about aggregate household debt, ownership of specific assets and the use of particular credit instruments in Waves 5, 10 and 15.

${ }^{4}$ In a companion paper, we use simple descriptive statistics to investigate the relationship between indebtedness and separation (Bridges and Disney, 2012).
} 
such as gambling or alcoholism that may lead to both outcomes. We handle this potential identification issue in a number of ways. We control for the direct effects of measurable shocks to the household's finances on indebtedness (e.g. resulting from job loss or some other shock to income). We do this by utilising changes in household expenditure and in the household's self-reported ability to finance its outgoings, both of which might also have an impact on separation, as measures of these 'direct effects'. Our results on the relationship between over-indebtedness and dissolution are robust to controlling for these direct effects. They are also robust to the inclusion of a series of 'shock' variables that might confound the arrears-separation relationship. Finally, we tackle identification by dealing with the arrearsseparation relationship in a two-equation system by exploiting instrumental variables that affect arrears but not separation. ${ }^{5}$

Another potential problem is reverse causality; couples that are experiencing relationship strain may change their behaviour to prepare for their impending separation, taking on an increased amount of debt or changing their labour force participation. We therefore examine the extent to which couples (especially the female partner) exhibit forward-looking behaviour in anticipation of separation. We find evidence that some households do change their behaviour prior to separation: in particular, married females may increase their labour supply prior to separation. Interestingly, however, while this may indicate an underlying intention of one or both parties to dissolve their relationship, the change in circumstances also appears linked in part to prior episodes of financial strain. For example, we find that a response to a sustained period of household over-indebtedness is for the female respondent to enter the labour market. The ensuing financial independence of the female partner may in turn trigger a later separation. Hence, the observed change in labour market behaviour appears linked to a previous or underlying financial problem within the home. Further support for the notion that

\footnotetext{
5 The question of simultaneity arises in other facets of the Becker model of family evolution - see, for example, the discussion of endogenous fertility and its relation to income shocks in Lindo (2010).
} 
what we are observing is indeed causal is that those couples at most risk from dissolution i.e. those that have reported a degree of relationship strain in the previous 12 months, do not appear to engage disproportionately in strategic behaviour prior to separation.

The structure of the remainder of the paper is as follows. In Section 2, we provide a brief overview of the literature on partnership instability and the role of household finances. In Section 3, we describe the data used in the paper, and provide some descriptive statistics. Section 4 provides our main empirical results while Section 5 concludes the paper.

\section{Background and Literature Review}

The established literature on the gains from marriage and the causes of marital instability (such as Becker et al., 1977; Weiss and Willis, 1997, Weiss, 1997) builds on Becker's (1973, 1974) theory of marriage. Becker argues that couples meet through a process of search and separate when the expected utility from remaining together falls below the expected utility from divorcing and possibly remarrying. Thus while a union between two individuals may initially seem optimal from the perspective of both partners, this assessment can subsequently change as a result of the arrival of new information, which may cause either partner to reevaluate the quality of the match.

The key point here is that this information must be unanticipated. Adverse events known to the couple at the outset or expected to occur should be taken into account in the decision to form the partnership. The future stability of the union is also affected by the initial quality of the match. If the gains from the partnership are large, small shocks should not destabilise the union. The probability of dissolution will thus be lower amongst couples well matched in terms of similar life experiences and goals. This last proposition has been established 
empirically by, for example, Böheim and Ermisch (2001), Charles and Stephens (2004), and Weiss and Willis (1997).

Less empirical research has examined how changing economic factors affect partnership dissolution decisions. In line with Becker's predictions, those studies that focus on economic factors tend to focus on unanticipated changes to family income. Becker et al. (1977) use cross-section data for the United States to show that both unexpectedly high and unexpectedly low male earnings have a positive effect on divorce. That finding used data for 1966 when divorce rates were relatively low; a more recent study by Starkey (1991) finds a similar result; large deviations between a husbands' actual and expected income increases the probability of divorce. In addition, Weiss and Willis (1997) show that expectations about earnings capacity formed at the time of the marriage have no effect on subsequent divorce rates; rather, it is changes in predicted incomes arising from new information that lead to separation. However, Hoffman and Duncan (1995) find that income and wage changes have only a small effect on marital dissolution.

How do household finances fit into this framework? The basic 'building block' of a structural model of indebtedness is the life cycle hypothesis of saving and consumption (expenditure) developed by Franco Modigliani and his collaborators. ${ }^{6}$ Here, a forwardlooking household uses the capital market to smooth its spending over the life cycle relative to fluctuations in its income stream and to changes in the household's composition (e.g. as a result of births and ageing). As such, there is a strong likelihood that a rational household will accumulate and decumulate wealth (and debts) over its lifetime (particularly in the form of collateralised debt - namely mortgages to finance house purchases) by utilising borrowing and savings to engage in 'consumption-smoothing'. Therefore, in line with Becker et al.'s (1977) notion that it is only new information that can destabilise a union, the accumulation of

6 See Ando and Modigliani (1963), Modigliani and Brumberg (1954, 1979). 
debt should not, in itself, be associated with partnership dissolution. Indeed, insofar as marriage is often seen by a financial provider as a signal of stability, couples may have access to a greater value of debt than those who are single (conditional on other characteristics such as age and income).

However, enhanced access to credit may expose the household to a greater risk of overindebtedness in the event of an unanticipated adverse shock to the couple's finances, such as the loss of one (or both) earners' incomes or health incapacity. Using borrowing to smooth spending over adverse short run shocks to household finances is potentially risky (Sullivan, 2008). For example, if a household uses borrowing to maintain spending during a spell of unemployment at a comparable level to when employed, there is the obvious danger that a subsequent adverse macroeconomic shock or other causes of difficulties in finding a job may expose that household to borrowing arrears. There is the important counter-balancing factor that a responsible lender might be cautious in lending to such a household; however, this in turn may drive the household into a borrowing arrangement on much less favourable terms outside the formal credit market. A key assumption of this paper is that, although some couples may voluntarily use loans or credit card debt to smooth expenditure, nobody would plan to enter into persistent arrears on debt or into bankruptcy given the long-term negative effect that default and persistent arrears can have on an individual's credit score and his or her ability to borrow money in the future. ${ }^{7}$

A second relevant issue concerns how persistent debt interacts with family formation. The accumulation of arrears on debt, and repeated episodes of over-indebtedness are often associated with persistently low household incomes and a lack of earnings capacity. Hence, the association between partnership instability and financial stress brought about by periods of indebtedness is more likely to occur in partnerships that are characterised by relative

\footnotetext{
${ }^{7} \mathrm{We}$ abstract from any strategic features of the bankruptcy decision; household strategic bankruptcy seems to be less common in the UK than in the United States and has been little analysed by economists in the UK.
} 
youthfulness, low-paying jobs, periods of unemployment, and other measures of financial hardship, especially if these episodes of financial stress persist for long periods.

Although empirical studies report an association between financial strain and conflict and stress among couples which increases the likelihood of a relationship failing (Sullivan, Warren and Westbrook, 2000) few studies have looked at the impact household indebtedness has on partnership dissolution, let alone with recent data. This reflects the paucity of suitable data sets with precise measures of financial indebtedness and arrears, especially in Britain. Instead, the available evidence tends to concentrate on financial strain brought about by job loss and the resultant loss of income. Attewell (1999) and Charles and Stephens (2004) argue that job displacement raises the risk of marital breakdown, while Duncan and Hoffman (1985) find that pre-divorce income levels are lower in households that are about to divorce than those that do not. On a related issue, Böheim and Ermisch (2001) show that those couples who experience an unexpected improvement in their financial situation are less likely to dissolve their partnership, while Fisher and Lyons (2006) focus on the relationship between bankruptcy and divorce. ${ }^{8}$ We address this gap in the literature, looking specifically at the role that household indebtedness and arrears plays in partnership dissolution using data from the Families and Children Survey.

Finally, we also study the extent to which changes to the way the household organises its finances precedes partnership dissolution. Although, Becker et al. (1977) argue that marital instability is triggered by unanticipated changes in circumstances, some changes are clearly endogenous, and changing economic circumstances may indicate the intention of one or both

\footnotetext{
${ }^{8}$ There is also a literature that focuses on the financial consequences of divorce, which are often harsh and persistent, especially if the divorcee does not remarry. Fisher and Lyons (2006) focuses on financial insolvency following divorce, while Jenkins (2008) examines the effect marital dissolution has on income following divorce.
} 
partners to dissolve the relationship. ${ }^{9}$ For instance, women who forecast partnerships that are more fragile may choose to invest more in their careers. Although this is a relatively unexplored area of research, Johnson and Skinner (1986) using panel data for the United States find that women who subsequently divorce increase their labour supply in the three years prior to separation. They argue that this increased labour force participation arises because the female respondent anticipates the future dissolution of the union and therefore seeks to improve her position in the labour market so that she can support herself financially after the divorce. On a related issue, the introduction of no-fault unilateral divorce laws in the United States led to an increase in the labour supply of married women (see, Parkman, 1992; Stevenson, 2008; and Genadek et al., 2007). ${ }^{10}$

\section{Data and Descriptive Analysis}

\subsection{The Families and Children Survey}

We use data from a large random sample of couples with children drawn from Britain's Families and Children Survey (FACS) over the period 2001-2008. ${ }^{11}$ The FACS was first established in 1999 as a survey of low income families. The original sampling frame comprised all sampled lone parents with children, and couples with children where the household worked less than 16 hours a week, and/or received Family Credit ${ }^{12}$, or whose income was no more than 35 percent above the point at which they would have been entitled

\footnotetext{
${ }^{9}$ In passing, this last finding shows the difficulty of looking at the impact of separation or divorce on the financial position of ex-partners when either partner had already taken steps to change their economic position prior to the dissolution of the partnership. However, this issue is of greater relevance to studies of the economic effects of partnership dissolution, which is not the topic in this paper.

${ }^{10}$ No-fault unilateral divorce laws allow either spouse to obtain a divorce without the consent of his or her partner, thereby reducing the cost of divorce.

${ }^{11}$ Due to funding cuts, the last wave of this survey was in 2008, which is unfortunate since the Great Recession would have created a perfect natural experiment.

${ }^{12}$ Between 1988 and October 1999, Family Credit was the main in-work benefit in Britain. It was paid to women and was designed to encourage low-income families with children to remain in work. In order to be eligible for Family Credit, a family with children needed to have at least one adult working more than 16 hours a week. In October 1999, Family Credit was replaced by the Working Families' Tax Credit, which was replaced by a combination of the Working Tax Credit and the Child Tax Credit in April 2003. Family Credit and its successors are similar to the Earned Income Tax Credit in the United States.
} 
to Family Credit. ${ }^{13}$ The same sample of families was then re-interviewed in 2000. In 2001 the sample was increased to encompass a representative sample of all families with children, and has continued thereafter in this format. In what follows we make use of the sample from 2001 onwards when the survey became representative of all families with children.

The FACS asks standard questions on household demographics, health, education, labour market activities (including job search) and income sources, including questions on eligibility for tax credits and other welfare benefits. Uniquely for the UK, however, the survey collects information on financial hardship in each wave together with details of the nature of credit and borrowing arrangements, and the extent of individual arrears (on these credit instruments and on specific household bills). The FACS also collects information on the type and level of savings and investments, although it only collects information on the value of any loans outstanding from 2003 onwards.

Finally, respondents who live in couples are asked a series of questions about how they manage and organise their household's finances using a typology developed by Pahl (1989) that is now widely used in the literature. Responses range from the household having independent finances to systems of money management where either the female/male partner manages the entire household's money. ${ }^{14}$

At each yearly interview, respondents are also asked to update their relationship status. Those in a relationship are asked when they first met, when they began to share a home together, and whether they are married to their current partner. Individuals whose present relationship began after the conception of their eldest child are invited to provide details of

\footnotetext{
${ }^{13}$ The financial status of households in the first wave is analysed in Bridges and Disney (2004).

${ }^{14}$ Pahl (1989)'s system of money management comprises: (1) the female whole-wage system where the wife manages the household's money (except the husband's personal spending money); (2) the male whole-wage system where the husband manages all the household's finances; (3) the housekeeping allowance system where the husband manages most of the money (except for the wife's housekeeping allowance); (4) the pooling system where household money is pooled and managed jointly; and (5) the independent management system where both partners have a separate source of income.
} 
any relationships that took place from the year before their eldest child was born, which can be used to provide information about behaviour prior to the respondent's current relationship. This includes whether they were married before, the length of any previous relationships, and whether they have any children from a past relationship.

Although a large proportion of families still comprise of 'traditional' married couples with children, individuals are increasingly experiencing family life within a cohabiting couple (ONS, 2007). We therefore include both married and cohabiting partnerships in our sample of couples. ${ }^{15}$ In addition, and in contrast to many other household surveys, in the FACS the respondent for the most part is the female partner within a couple (i.e. the respondent is normally a woman). ${ }^{16}$

Single parents and couples with children are the groups within the population that are particularly at risk from financial difficulties given housing and child-related expenditures. Therefore, although the FACS is not representative of the whole population, it nevertheless constitutes a large random sample of households who are disproportionately at risk of financial hardship. We do not attempt to assess the 'representativeness' of this sample relative to the population as a whole. We will not capture, for example, the increasing phenomenon of divorce occurring when children leave home and/or one or other of the partners retires from full-time work. On the other hand, unlike some psychological studies, our data set avoids the natural issue of inference arising using selective samples based on those exhibiting evidence of financial stress.

\footnotetext{
${ }^{15}$ Between 1996 and 2006 there was a 60 percent increase in the number of cohabiting couple families (ONS, 2007). Official statistics suggest that divorce rates rose in the early 1990s and the early 2000s and declined in each decade thereafter. There has been a trend over the whole period towards later marriages. Civil partnerships have been enacted in England and Wales since 2005; dissolution rates are high but still make up a small proportion of overall separations.

${ }^{16}$ The respondent's partner is also interviewed separately in certain sections of the survey, and where this is not possible proxy questions are asked of the main respondent. However, this information is not always complete.
} 
The precise data set constructed for the empirical analysis is as follows. We utilise annual observations on married and cohabiting female respondents who are at risk of their union dissolving in the following year, thereby identifying the financial characteristics of relationships that subsequently dissolve and not the effects of dissolution as such. We follow each individual until she leaves the sample or the survey ends since it is possible for the same individual to have more than one relationship, and thus be at risk of partnership dissolution more than once. Overall, this gives us a pooled set of 34,503 data points, being composed of yearly observations of couples.

\subsection{Descriptive Statistics}

Table 1 describes the key economic and financial characteristics of the pooled sample. Mean responses (standard deviations) are reported for the entire sample, and then separately by relationship status. The pooled sample of married/cohabiting respondents is split into four groups: (1) married throughout the sample period; (2) cohabiting throughout the sample period; (3) married but separated in $t+1$; and (4) cohabiting but separated in $t+1$. Summary statistics of the remaining variables used in this analysis by relationship status are presented in Table $1 \mathrm{~A}$ in the Appendix.

\section{$<<$ Table 1 here $>>$}

Table 1 shows that large differences exist in economic and financial status between those households that subsequently separate and those that stay together. On average, separating couples are less likely to be in employment, reflected in lower weekly earnings compared to their cohabiting/married counterparts. This is particularly true for cohabiting men, 73 percent of whom are in employment on separation compared to around 90 percent for those that do not separate. Separating couples are also less likely to be a homeowner (either outright or with a mortgage), have fewer savings, and are less likely to share the management and organisation of their finances than non-separating couples. 
Given this lack of earnings capacity and capital as collateral, separating couples prior to the dissolution of their partnership appeared on average to be less likely to access formal credit arrangements and instead made greater use of informal loan arrangements. They are more likely to have experienced repayment problems having accumulated arrears on their debts. For those with positive arrears, the average number of arrears per household is around 2.3 for those that subsequently dissolve their partnership, compared with around 2 for those that stay together - this includes not just arrears on credit and debt arrangements but also on utility bills, council tax bills, mortgages and rent.

These summary statistics establish a positive relationship between episodes of financial hardship, household over-indebtedness and partnership instability. We now examine more formally the extent to which the underlying economic position of the household is responsible for partnership dissolution or whether it is changes to that position that lead to dissolution.

\section{Empirical Strategy and Results}

\subsection{Empirical Strategy: Discrete-time Proportional Hazard}

We begin by estimating the determinants of partnership dissolution using a discrete-time proportional hazard, $h_{i t}$, where survival time is partnership duration. ${ }^{17}$ This approach models the baseline hazard flexibly and avoids any restrictive parametric assumptions about its shape. ${ }^{18}$ Suppose $T_{i}$ is a random variable representing time in a relationship, then the continuous time hazard, $\lambda_{i}(t)$ for individual $i$ at time $t$ representing the instantaneous rate at which individual $i$ separates is a proportional hazard model of the form:

\footnotetext{
${ }^{17}$ This is the model proposed by Prentice and Gloecker (1978), and outlined in Jenkins (1995, 1997).

${ }^{18}$ Imposing a parametric specification on the shape of the hazard can bias the estimated effects of the time varying economic variables and the baseline hazard (Narendranathan and Stewart, 1993).
} 


$$
\lambda_{i}\left(x_{i}, t\right)=\lambda_{0}(t) \exp \left(x_{i}(t)^{\prime} \beta\right)
$$

where $\lambda_{0}(t)$ is the baseline hazard, and $x_{i}(t)$ is a vector of time-varying observable characteristics thought to affect partnership stability with coefficients $\beta$. The probability that individual $i$ separates from her partner at time $t+1$, conditional on the spell being uncompleted at time $t$ (i.e. the discrete-time proportional hazard, $h_{i t}$ ) can then be written as a function of the continuous time hazards:

$$
h_{i}(t)=\operatorname{Pr}\left(T_{i}<t+1 \mid t \leq T_{i}\right)=1-\exp \left(-\int_{t}^{t+1} \lambda_{i}(u) d u\right)
$$

Combining (1) and (2) gives:

$$
\begin{aligned}
& h_{i}(t)=1-\exp \left(-\int_{t}^{t+1} \lambda_{0}(u) \exp \left(x_{i}(t)^{\prime} \beta\right) d u\right) \\
& \left.=1-\exp \left[-\exp \left(x_{i}(t)^{\prime} \beta\right)+\gamma(t)\right)\right]
\end{aligned}
$$

where $\gamma(t)=\ln \int_{t}^{t+1} \lambda_{0}(u) d u$ captures the degree of duration dependence in the hazard of separation.

We model duration dependence non-parametrically using as a series of time dummies, which take the value one in each year if the couple has been in a relationship that has lasted at least $t$ years. ${ }^{19}$ Since some of the partnerships are likely to have been formed prior to the respondent entering the survey, we use the relationship history data in the sample to calculate the duration of the partnership.

In addition, since some respondents are only interviewed after they become at risk of separation their entry is said to be delayed, and hence the contribution to the likelihood function of these unions must therefore be conditioned on surviving in the union until entering the survey. Jenkins (1995) shows that the resulting log-likelihood function is similar

\footnotetext{
${ }^{19}$ The resulting transformation is known as the complementary log-log transformation.
} 
to the expression without delayed entry, other than that the summations are from the year when the relationship began to the year when last observed. ${ }^{20}$

The model discussed so far assumes homogeneity of the survival distribution across individuals. However, if there are systematic individual differences in the distribution after controlling for observables, problems of interpretation can arise (see Lancaster, 1979). Hence we control for heterogeneity by conditioning the model on an individual's unobserved characteristics, $v_{i}$. Now the continuous time hazard becomes:

$$
\lambda_{i}\left(x_{i}, t\right)=v_{i} \lambda_{0}(t) \exp \left(x_{i}(t)^{\prime} \beta\right)
$$

and the corresponding discrete-time hazard function is:

$$
h_{i t}=1-\exp \left[-\exp \left(x_{i}(t)^{\prime} \beta\right)+\gamma(t)+\log \left(v_{i}\right)\right]
$$

where $v_{i_{i}}$ is a normally distributed random variable with mean zero.

Finally, in specifying our hazard function we also allow for repeated events. As already mentioned, it is possible for the same individual to have more than one relationship, and thus be at risk of partnership dissolution more than once. ${ }^{21}$ As a result, all specifications have robust standard errors clustered on the individual to account for any correlation across spells. $^{22}$

\footnotetext{
${ }^{20}$ In other words, with delayed entry at time $u_{i}$ for individual $i$, we have to condition on survival up to time $u_{i}$ (Jenkins, 1995):

$L_{i}=\left(\frac{h_{i j}}{1-h_{i j}}\right)^{c_{i}} \prod_{k=1}^{j}\left(1-h_{i k}\right) / S_{i}\left(u_{i}\right)$. But $S_{i}\left(u_{i}\right)=\prod_{k=1}^{u_{i}}\left(1-h_{i k}\right)$ where $c_{i}=1$ if a spell is completed and $c_{i}=0$ if a spell is right-censored. Now the log-likelihood function becomes:

$\log L_{i}=\sum_{k=u_{i}+1}^{j}\left[y_{i k} \log h_{i k}+\left(1-y_{i k}\right) \log \left(1-h_{i k}\right)\right]$.

This is similar to the expression if there was no delayed entry (Jenkins, 1995).

${ }^{21}$ Around 4 percent of couples have more than one relationship during the sample period.

${ }^{22}$ Estimation is performed using the STATA program xtcloclog with the data organised in person-year form (see, Jenkins, 1995, 1997).
} 


\subsection{Household Finances and Partnership Dissolution: Baseline Specification}

Maximum likelihood estimates for the hazard of separation, controlling for unobserved heterogeneity, are in Table 2. Results are presented separately for cohabiting and married couples. For each regression, the table provides details of the hazard ratio, which measures the proportional effect on the underlying (instantaneous) hazard of separation of a one-unit change in a variable. Explanatory variables include controls for characteristics at the start of the relationship, the quality of the match, household demographics, and a rich set of variables designed to capture the economic and financial position of the household.

\section{<<Table 2 here >>}

We begin with a brief discussion of how relationship and household demographic variables affect partnership stability, before turning our attention to the key point of the paper: the role of debt instruments, and episodes of financial stress. Clear differences emerge between our cohabiting and married couples when we look at the effect that relationship and household demographic variables have on partnership dissolution.

For both types of couples, the older the age of the respondent at the start of the relationship, the lower is the likelihood that the partnership will fail. Differences in age between the respondent and her partner are also important for married couples; married couples where the respondent is older (normally, here, the female respondent) are more likely to separate. Such findings are in line with both the theoretical literature and previous empirical findings: see inter alia Böheim and Ermisch (2001) and Charles and Stephens (2004). For married couples, family formation is also important. The presence of a young child (under the age of 4) helps to stabilize a marriage but, overall, a higher number of children increase the probability of dissolution. Other empirical findings on this are contradictory and may reflect national traits: Böheim and Ermisch (2001) using British data find a similar result, but empirical studies for the United States find that the number of 
children has a negative effect on dissolution (as in Weiss and Willis, 1997 and Charles and Stephen, 2004).

The key finding for cohabiting couples is the length of the relationship as captured by the indicators of duration dependence. We observe a monotonic decrease in the hazard of separation among cohabiting couples as their relationship length increases. This confirms the existing literature: see inter alia Hoffman and Duncan, 1995; Charles and Stephens, 2004. Relationships of longer duration are likely to possess more share capital, making them less likely to fail. The couple's system of money management is also important, and our results show that couples (both cohabiting and married) that have shared finances are less likely to separate.

In the context of the present paper, of particular interest is the effect the economic and financial position of the household has on the likelihood of separation. Households where the male partner is in employment are less likely to separate, whilst for those who are married, female employment has a positive effect on the hazard of separation, raising the hazard of separation by 42 percent. Household assets and debts are also important. For both types of couples, home-ownership (either outright or with a mortgage) lowers the incidence of separation while for married couples the number of savings accounts lowers the hazard of separation by 15 percent. Such a finding is in line with expectations. As the nature of a couple's commitment becomes more explicit in marriage, resources are often pooled (Singh and Lindsay, 1996). Hence, home-ownership, which often leads to the pooling of resources, may be viewed as a sign of commitment.

As already mentioned, in line with Becker et al.'s (1977) notion that it is only new information that can destabilise a union, the accumulation of debt should not in itself be associated with partnership dissolution. However, high levels of borrowing may expose the household to a greater risk of over-indebtedness in the event of an unanticipated income 
shock (Disney et al., 2008), leading to tensions within the home that may pose a risk to the mental-wellbeing of its members (Bridges and Disney, 2010), and the stability of the partnership (Eurofound, 2013).

We find that, although the number of formal loans (e.g. from a Bank, Building Society, finance company or similar institution) has no significant effect on partnership dissolution, over-indebtedness, captured by the number of debts (including household bills) where the household is in arrears, has a positive effect on the likelihood of separation. In this instance, a one-unit increase in the number of debts in arrears raises the hazard of separation by 26 percent for married couples, and 8 percent for cohabiting couples, respectively.

We now subject our empirical analysis to a number of robustness checks by considering alternative specifications of the baseline specification, and the timing of events. We also address potential concerns in establishing causality from financial strain to separation.

\section{Sensitivity Analysis}

\subsection{Alternative Measures of Arrears and Definitions of Financial Strain}

Next, we investigate whether the observed positive effect of over-indebtedness on partnership instability is robust to alternative measures of arrears and the inclusion of different measures of financial strain (Table 3). First, we control for the value of arrears, as a series of dummy variables, instead of the number of debts in arrears (panel 1) and find that, for cohabiting couples, arrears of $£ 1000$ or less have a positive effect on separation, while for married couples the oppose is true, and it is arrears greater than $£ 1000$ that trigger dissolution.

\section{$<<$ Table 3 here $>>$}


Second, in describing the acquisition of debt, economists often think of a 'hierarchy' of debt arrangements, ordered by ease of access or by the costs of borrowing, such as the current and prospective interest rate. The 'rational' borrower would therefore choose the debt portfolio that minimises the expected cost of financing the target level of debt. As such, although debt should not in itself lead to separation, the same may not be true of borrowing from informal sources such as a money lender or 'tally man', friend or relative, or having a loan or advance on wages from an employer. Borrowing from informal sources may be the type of borrowing that households resort to because they are denied access to formal credit arrangements. In panel 2 of Table 3, we add loans from informal sources to the baseline specification, and find that taking out a loan from an informal source has a positive effect on separation. This provides further evidence that separation is triggered by financial strain.

Next, since FACS only collects information on the value of loans from 2003 onwards, in the baseline specification we control for the number rather than the value of loans. In panel 3 , we show that our results are robust to controlling for the ratio of debt to earnings, rather than the number of loans outstanding, and find that for married couples, this ratio of debt to earnings (another indicator of financial strain) has a positive effect on separation.

Finally, we look at the effect the timing of events has on partnership dissolution. In panel 4, we add arrears lagged one and two years in the past to the baseline specification, and find that it is current rather than lagged arrears that trigger separation. This provides support for the notion that it is only 'surprise' events that have an (immediate) impact on partnership dissolution; couples having already dealt with the effect of past shocks. On a related issue, Charles and Stephens (2004) find that job loss has the biggest impact on dissolution immediately following the shock. We also examine whether persistent over-indebtedness in the past, namely being in arrears on debt in $t-1$ and $t-2$ has an impact on separation (panel 5). 
Again, we find that separation is triggered by current rather than lagged arrears. Existing theory is consistent with these results insofar as these financial difficulties are unanticipated.

\subsection{Endogeneity (I): Omitted Variables}

So far, the analysis has shown that there is an association between arrears and dissolution. A basic problem in establishing causality from arrears to partnership dissolution is that any observed change in behaviour prior to separation may also be a response to an unanticipated change or 'shock' elsewhere to the household. It is, for example, possible to think of numerous potential 'shocks' to the household that may simultaneously increase both arrears and the likelihood of separation. For example, a job loss by one or both partners may lead to the accumulation of debt as households utilise borrowing to maintain spending at existing levels, or it may lead to episodes of over-indebtedness as households find it difficult to service existing debts. As such the baseline specification outlined in Table 3 may also be capturing the effect variables not central to our proposed arrears-separation relationship have on dissolution. ${ }^{23}$

Given the rich nature of the FACS we handle this potential identification issue by adding controls for these missing 'shock' variables to the baseline specification (Table 4a). Conditional on measuring these changes we examine whether there is any residual effect of arrears on dissolution. If arrears continue to have an impact on separation, then we argue that we have an independent effect of arrears on separation. Column 1 controls for changes in household income. Column 2 includes changes in family circumstances, which one might expect to yield falling income, including job loss, worsening health, and changes in family composition. We find that our results are robust to the inclusion of these missing 'shock' variables. Of the shock variables, deteriorations in health have a positive effect, whilst the

\footnotetext{
${ }^{23}$ Although it should be noted that in Table 3 (and in all other specifications) we control for unobserved heterogeneity.
} 
birth of a child lowers the risk of dissolution. The loss of a job by either partner is insignificant. $^{24}$

\section{$<<$ Table 4a here $>$}

Alternatively, we could address this potential identification issue by controlling directly for the effects shocks to the household (whatever their cause) have on indebtedness. For example, an increase in the level of household debt usually arises as a result of a decrease in the ability to pay (e.g. as a result of a job loss or some other negative income shock), or an increase in consumption, both of which may have a direct effect on relationship stability. In Table $4 \mathrm{~b}$, we utilise changes in household expenditure and in the household's self-report ability to finance its outgoings, to capture these direct effects. ${ }^{25}$

\section{$<<$ Table 4b here $>$}

As before we argue that if arrears continue to have an impact on dissolution, after controlling for these additional variables, we have an independent effect of arrears on dissolution. Once again, we find that our results are robust to the inclusion of these missing variables.

\subsection{Endogeneity (II): Instrumental Variables}

Our second approach to tackling identification deals directly with the arrears/separation relationship in a two-equation system by exploiting instrumental variables that affect arrears but not separation. Although instrumental variables are used extensively in the social sciences and economics to tackle endogeneity, the use of instrumental variables in duration models is

\footnotetext{
${ }^{24}$ Of course, any repayment problems might be the consequence of a past shock, and we therefore also examine the extent to which the results are robust to the inclusion of lagged changes in household circumstances. We find that our results are robust to the inclusion of lagged shock variables. These results are not reported here but are available upon request.

${ }^{25}$ We are able to model explicitly changes to the household's financial situation over the past 12 months and the impact this may have on consumption and ability to pay. FACs asks respondents whether their financial situation has got better/worse over the past 12 months. For those whose situation has changed they are asked the reason for this change, which includes changes to consumption (having to buy more/fewer things), and ability to pay (having to manage on less/more money), and we use the responses to these question to control for the direct effects shocks to the household may have dissolution.
} 
relatively less developed. We use this as an opportunity to test how robust our results are to controlling for endogeneity using a two-stage probit regression (Newey, 1987).

We estimate the probability of separation $\left(d_{i t}=1\right)$ using a latent variable model of the form:

$$
\begin{aligned}
& d_{i t}^{*}=\delta A_{i t}+x^{\prime}{ }_{1 i t} \beta_{1}+u_{1 i t} \\
& A_{i t}=x_{1 i t}^{\prime} \pi_{1}+x^{\prime}{ }_{2 i t} \pi_{2}+u_{2 i t}
\end{aligned}
$$

where $d_{i t}^{*}$ is the latent (unobserved) propensity of separation for individual $i$ at time $t$, $A_{i t}$ is our measure of over-indebtedness (arrears), $X_{1 i t}$ is a vector of exogenous variables, $X_{2 i t}$ is a vector of additional instruments, and by assumption the errors are: $u_{1 i t}, u_{2 i t} \sim N(0, \Sigma)$.

In order to find valid instruments for arrears, we draw on the literature on financial exclusion. One such variable is having a prepayment electricity meter. Notwithstanding the prevalence of various forms of borrowing and financial debt, the most common form of arrears is being behind with utility bills, including gas, water and council tax. Electricity bills are however less prone to arrears, which may be explained by the fact that households at most risk of financial difficulties have often had a prepayment electricity meter installed (Bridges and Disney, 2004), making it impossible for them to fall behind on this particular bill. Thus having a prepayment electricity meter is an indicator that the household may be experiencing repayment problems on other credit and debt instruments.

As a second set of instruments, we include a selection of dummy variables that indicate whether our couples are able to afford to take part in certain everyday events (e.g. have a celebration with presents, for friends and family at special occasions like birthdays), or own certain basic items (e.g. two pairs of all-weather shoes for each adult). These are events/items that the population rank as being "necessary, which all adults should be able to afford and which they should not have to do without" (Gordon et al., 2000: page 1). 


\section{$<<$ Table 5 here $>>$}

Table 5 reports estimates of the probability of separation for cohabiting and married couples, respectively. Tests for over-identification show that the instruments are valid. ${ }^{26}$ Although the model structure is rather different from that of the duration models estimated in the previous sub-sections, similar results emerge and the results once again indicate a positive relationship between arrears and separation.

To summarize, relationships beset by financial strain are more likely to fail, and this finding is robust to a number of alternative specifications and the inclusion of different measures of financial strain. Furthermore, the findings suggest that the direction of causality is from arrears to dissolution.

\section{Symmetry of Shocks and Plans for Dissolution}

\subsection{Symmetry of Shocks}

The analysis so far and in much of the literature focuses on the effect financial strain has on partnership stability. In Table 6, we examine whether there is any evidence that changes in economic and financial circumstances are symmetric i.e. whether both positive and negative changes trigger partnership dissolution, relative to those whose economic and financial situation remains unchanged. If these changes, whether positive or negative, were unanticipated by one or other partner at the start of the union, they would be consistent with Becker's model of partnership matching and dissolution.

In line with our earlier discussion, we find that the accumulation (and decumulation) of collateralised debt - namely mortgages to finance house purchases - has little impact on partnership dissolution. However, for both types of couples, changes to other aspects of the

\footnotetext{
26 These are tests of the joint null hypothesis that the excluded instruments are valid instruments, i.e. uncorrelated with the error term and correctly excluded from the estimated equation.
} 
household's economic and financial position, both favourable and unfavourable, have a positive effect on dissolution.

\section{$<<$ Table 6 here $>>$}

We find that an increase in the level of over-indebtedness within the household, measured by an increase in the number of debts in arrears has a positive effect on dissolution, raising the hazard of separation by around 90 percent for both types of couples. For cohabiting couples this variable is symmetric; an improving economic position captured by a reduction in the number of debts in arrears also has a positive effect on dissolution. Likewise, for cohabiting couples a decrease in the use of formal loans is positive. For married couples deterioration in health and the male partner entering employment has a positive effect on dissolution. In Table 2A in the Appendix, we decompose the route the male partner takes into employment as being from unemployment, or out of the labour market (e.g. because of education, sickness or family care). We find that for married couples both routes into employment have a positive effect on the hazard of separation, which provides support for the idea that it is the improvement in economic circumstances resulting from finding employment (rather than any negative effect that may have arisen because of an earlier job loss) that is behind this positive result.

Of course, a change in economic circumstances may also indicate the intention of one or both parties to dissolve their partnership; couples that are experiencing relationship strain may change their behavior to prepare for their impending separation. For example, the reduction in indebtedness observed prior to dissolution may be in line with credit counselling advice, which states that individuals should leave a partnership with no joint debts, if possible, and we return to this issue in the next section. 


\subsection{Planning for Dissolution}

Next, we investigate whether there is any evidence that couples (especially the female partner) plan for separation. As mentioned in Section 2, although this is a relatively unexplored area of research, there is some evidence of forward-looking behaviour by women prior to separation. For example, Johnson and Skinner (1996) find that women who subsequently divorce increase their labour supply prior to separation, and argue that rising divorce rates may account for one-third of the unexplained increase in women's post war labour force participation.

We start by examining the effect female job search has on partnership dissolution. The FACS asks its female respondents a series of questions relating to their job search, including whether they have been looking for paid work of 16 hours or more a week at any time during the past 12 months (Table 7). For married females, we find that those who report that they have been searching for paid work of 16 hours or more and are successful in increasing their labour supply are more likely to separate (column 1$){ }^{27}$

\section{<<Table 7 here >>}

Next, we attempt to identify the motivation behind this decision to enter the labour market and/or work more hours, and the extent to which the decision is linked to the underlying economic and financial position of the household. Table 7 suggests that the positive association between increased labour supply and separation appears, at least in part, to be related to episodes of financial strain in $t-1$. Interacting successful job search with the level of over-indebtedness in the household in $t$ - 1 has an increasingly positive effect on the incidence of separation (column 2). Such a finding also holds if we interact successful job search with the number of outstanding loans (both formal and informal) in $t-1$ (column 3 ), and if the male partner loses his job in $t-1$ (column 4).

\footnotetext{
${ }^{27}$ This variable is insignificant for cohabiting couples, and Table 7 reports results for married couples only.
} 
In other words, it is households where the female partner enters the labour market following an episode of financial strain that are more likely to separate. Table $3 \mathrm{~A}$ in the Appendix, which illustrates the results for the fixed effect (conditional) logistic model for the probability of job search, further supports this point by showing that a married female's decision to search for a job appears to be strongly linked to a worsening financial situation in the home.

Further support for the notion that we are observing a causal relationship between financial strain and separation can be seen if we look at the behaviour of couples whose relationships are already under strain, since this is the subset of couples we would expect to engage in strategic behaviour prior to separation. For both types of couples we find that those who report that they have lived apart from one another in the past 12 months excluding breaks for work or study (i.e. couples in 'strained' relationships), are more likely to dissolve their partnership (Table 8).

\section{<<Table 8 here $>>$}

We interact this measure of relationship strain with: (1) successful job search (panel 1); (2) the level of over-indebtedness (panel 2); and (3) the number of outstanding loans (panel 3). We find that for this subset of couples, the decision by the female respondent to enter the labour market and/or work more hours has no significant effect on separation. In addition, increasing levels of over-indebtedness and the accumulation of loans appear to decrease rather than increase the incidence of separation. As such, there seems to be no evidence that these couples engage disproportionately in strategic behaviour prior to separation. ${ }^{28}$

Combining these findings, the following story emerges. There is some evidence that households change their behaviour prior to separation; married females increase their labour

\footnotetext{
${ }^{28}$ Similar results hold if we change our variable measuring relationship strain to those who have ever lived apart from their partner/spouse.
} 
supply prior to separation. However, although this may indicate an underlying intention of one or both parties to dissolve the relationship, this change in circumstances also appears to be linked, at least in part, to an episode of financial strain in the previous year. In addition, there appears to be no evidence of strategic behaviour among the subset of couples whose relationships appear to be unstable.

\section{Conclusion}

Persistent financial problems, especially over-indebtedness, and adverse shocks to the household such as loss of employment, are widely seen as contributory factors to marital breakdown and civil partnership dissolution. Studies of these phenomena are limited by a lack of data; in particular, post-separation psychological studies of contributory stress factors often rely on data drawn from self-selecting samples. The present study therefore uses a relatively novel data set for Britain that contains a rich array of measures of financial stress as well as a careful demarcation of family circumstances to analyse these issues. Using a hazard specification that controls for unobserved heterogeneity, we show that specific measures of financial stress - in particular, arrears on household debts - are strong predictors of separation.

This finding appears to reinforce assertions in the media that periods of economic instability - notably, in recent times, the growing indebtedness of families in the run-up to the Great Recession from 2008 and the subsequent downturn in family finances - have been a factor behind an upward blip in the divorce rate. ${ }^{29}$ However, in the more general context of economic models of marriage and separation, our initial finding is tempered in two respects.

\footnotetext{
29 See, for example $B B C$ News "Divorce rate up 'because of recession' report says", 6 February 2014, http://www.bbc.co.uk/news/uk-26070256. However, while the number of divorces rose slightly from 2010 to 2012, the divorce rate (notwithstanding the BBC headline) has been falling for some years.
} 
First, the established theory of separation predicts that any substantial unanticipated shock of economic and financial circumstances of the partnership may induce separation - whether a windfall gain or a substantial loss in earning power. We find some support for this hypothesis: for example, reductions in indebtedness among cohabiting couples and increased labour income in married couples are also factors that increase the subsequent likelihood of separation as, of course, are positive indicators of increasing financial stress.

This raises the possibility, noted elsewhere in the literature, that partners in relationships who anticipate or intend a subsequent dissolution take prior steps to ensure their financial independence on dissolution. Hence, we also provide some tentative evidence that changes in household economic management of this type are predated by periods of financial stress. For example, more active job search by the female partner is associated with having had a larger number of outstanding financial loans and arrears in the previous period.

Reforms to divorce law are under active consideration in England and Wales, such as making the divorce process easier (and less expensive). Some reformers are advocating 'no blame' divorce, but at the same time are concerned about the effects of divorce on children and other family members. To the extent that divorce is driven by short run economic stress, such as over-indebtedness, the potential costs of divorce - both pecuniary and social - may be considerable, compared to settings in which divorce is planned and a result of a longer term breakdown in the relationship. Our results provide evidence that economic stress to the household is a factor in the separation of partnerships, but also that partners have often begun to prepare for dissolution in advance - for example, by the manner in which family finances are organised and in the changing employment status on both partners. Our results should contribute to the ongoing discussion on the costs and benefits of divorce reform. 


\section{References}

Ando, A., and Modligliani, F. (1963). The Life-Cycle Hypothesis of Saving: Aggregate Implications and Tests. American Economic Review, Vol. 53, pp. 55-84.

Attewell, P. (1999). The Impact of Family on Job Displacement and Recovery, The Annals of the American Academy of Political and Social Science, Vol. 562, The Evolving World of Work and Family: New Stakeholders, New Voices, pp. 66-82.

Becker, G. (1973). A Theory of Marriage: Part I, Journal of Political Economy, Vol. 81(4), pp. 813-846.

Becker, G. (1974). A Theory of Marriage: Part II, Journal of Political Economy, Vol. 82(2), pp. S11-S26, Part II.

Becker, G., Landes E., Michael, R. (1977). An Economic Analysis of Marital Instability, Journal of Political Economy, Vol. 85(6), pp. 1141-1187.

Bridges, S. and Disney, R. (2004). Use of Credit and Arrears on Debt among Low Income Families in the United Kingdom, Fiscal Studies, Vol. 25 (March), pp. 1-24.

Bridges, S. and Disney, R. (2010). Debt and Depression, Journal of Health Economics, Vol. 29(3), pp.388-403.

Bridges, S. and Disney, R. (2012). Household Indebtedness and Separation in Britain, Evidence from the Families and Children Survey, Child and Family Law Quarterly, Vol. 24(1), pp. 24-38.

Böheim, R. and Ermisch, J. (2001). Partnership Dissolution in the UK - The Role of Economic Circumstances, Oxford Bulletin of Economics and Statistics, Vol. 63(2), pp. 197-208. 
Chamberlain, G. (1980). Analysis of Covariance with Qualitative Data, Review of Economic Studies, Vol. 47, pp. 225-238.

Chamberlain, G. (1984): Panel Data, in Griliches, Z. and Intriligator, M. (ed.), Handbook of Econometrics, Vol. 2, , Chapter 22, pp. 1247-1318, Elsevier Science.

Charles, K. K., and Stephens, M. Jr. (2004). Job Displacement, Disability, and Divorce. Journal of Labor Economics, Vol. 22, pp. 489-522.

Disney, R., Bridges, S., and Gathergood, J. (2008). Drivers of Over-Indebtedness: Report to the Department for Business, Enterprise and Regulatory Reform. Centre for Policy Evaluation, University of Nottingham.

Duncan, G. and Hoffman, S. (1985). A Reconsideration of the Economic Consequences of Marital Dissolution, Demography, Vol. 22(4), pp. 485-497.

Eurofound (2013). Household Over-indebtedness in the EU: The Role of Informal Debts, Publications Office of the European Union, Luxembourg.

Ferrie, J., Shipley, M., Stansfeld, S., Davey Smith, G., Marmot, M. (2003). Future Uncertainty and Socio-economic Inequalities in Health: the Whitehall II Study, Social Science and Medicine, Vol. 57, pp. 637-646.

Fisher, J. and Lyons, A. (2006). Till Debt do us Part: A Model of Divorce and Personal Bankruptcy, Review of Economics of the Household, Vol. 4(1), pp. 35-52.

Genadek, K., Stock, W., and Stoddard, C. (2007). No-Fault Divorce Laws and the Labor Supply of Women with and without Children, Journal of Human Resources, Vol. 42(1), pp. $247-274$.

Gordon, D., Adelam, L., Ashworth, K., Bradshaw, L., Levitas, R., Middleton, S. et al (2000). Poverty and Social exclusion in Britain, York: Joseph Rowntree Foundation 
Hoffman, S. and Duncan, G. (1995). The Effect of Incomes, Wages, and AFDC Benefits on Marital Disruption, Journal of Human Resources, Vol. 30(1), pp. 19-41.

Jenkins, S. (1995). Easy Estimation Methods for Discrete-Time Duration Models, Oxford Bulletin of Economics and Statistics, Vol. 57, pp. 129-138.

Jenkins, S. (1997). sbe17: Discrete Time Proportional Hazards Regression, STATA Technical Bulletin, Vol. 39, pp. 22-32.

Jenkins, S. (2008). Marital Splits and Income Changes over the Longer Term, Working Paper No. 7, Institute for Social and Economic Research, Colchester: University of Essex.

Johnson, W. and Skinner, J. (1986). Labor Supply and Marital Separation, American Economic Review, Vol. 76, pp. 455-469.

Kempson E., McKay, S. and Willitts, M. (2004). Characteristics of Families in Debt and the Nature of Indebtedness, Department of Work and Pensions Research Report 211, Leeds: Corporate Document Services.

Lancaster, T. (1979). Econometric Methods for the Duration of Unemployment, Econometrica, Vol. 47, pp. 939-956.

Lindo, J. (2010) 'Are children really inferior goods? Evidence from displacement-driven income shocks', Journal of Human Resources, 45, 2, pp. 301-327.

Modigliani, F. and Brumberg, R. (1954). Utility Analysis and the Consumption Function: An Interpretation of Cross-section Data, pp. 388-436 in K. K. Kurihara (ed) Post-Keynesian Economics, New Brunswick, N.J.: Rutgers University Press.

Modigliani, F. and Brumberg, R. (1979) Utility Analysis and the Consumption Function: An Attempt at Integration, pp. 128-197 in Abel, A. (ed) The Collected Papers of France Modigliani, Volume 2, Cambridge, Mass: MIT Press. 
Narendranathan, W. and Stewart, M. (1993). Modelling the Probability of Leaving Unemployment: Competing Risk Models with Flexible Base-line Hazards, Applied Statistics, Vol. 42(1), pp. 63-83.

Newey, W. (1987). Efficient Estimation of Limited Dependent Variable Models with Endogenous Explanatory Variables, Journal of Econometrics, Vol. 36, pp. 231-250.

Pahl, J. (1989), Money and Marriage, Macmillan, London.

Parkman, A. (1992). 'Unilateral Divorce and the Labor-Force Participation Rate of Married Women, Revisited', American Economic Review, Vol. 82(3), pp. 671-678.

Prentice, R. and Gloeckler, L. (1978). Regression Analysis of Grouped Survival Data with Application to Breast Cancer Data, Biometrics, Vol. 34, pp. 57-67.

OECD (2012). OECD Economic Outlook, Vol. 2012/1, OECD Publishing.

ONS (2007). Focus on Families, Office of National Statistics, Basingstoke, Palgrave Macmillan.

Stevenson, B. (2008). 'Divorce Law and Women's Labor Supply', Journal of Empirical Legal Studies, Vol. 5, pp. 853-873.

Singh, S. and Lindsay, J. (1996). Money in Heterosexual Relationships, Australian and New Zealand Journal of Sociology, Vol 32, pp. 57-69.

Starkey, J. (1991). Wives' Earnings and Marital Instability: Another Look at the Independence Effect, Social Science Journal, Vol. 28, pp. 501-521.

Sullivan, J. (2008). Borrowing during Unemployment: Unsecured Debt as a Safety Net, Journal of Human Resources, Vol 43(2), pp. 383-412. 
Sullivan, T., Warren, E., and Westbrook, J. (2000). The Fragile Middle Class. New Haven, CT: Yale University Press.

Vogler, C., Brockmann, M. and Wiggins, R. (2006). Intimate Relationships and Changing Patterns of Money Management at the Beginning of the Twenty-first Century, The British Journal of Sociology, Volume 57(3), pp. 455-482.

Weiss, Y. (1997). The Formation and Dissolution of Families: Why Marry? Who Marries Whom? and What Happens upon Divorce? in Rosenzweig, M., and Stark, O. (ed.), Handbook of Population and Family Economics, Vol. 1A, pp. 81-123, New York: Elsevier Science.

Weiss, Y. and Willis, R. (1997). Match Quality, New Information, and Marital Dissolution. Journal of Labor Economics, Vol. 15(1), pp. S293-S329.

Wildman, J. (2003). Income Related Inequalities in Mental Health in Great Britain: Analysing the Causes of Health Inequality over Time, Journal of Health Economics, Vol. 22 (2003), pp. 295-312. 
Table 1: Summary Statistics

\begin{tabular}{|c|c|c|c|c|c|c|c|c|}
\hline \multirow[t]{2}{*}{ Variable } & \multicolumn{2}{|c|}{ Cohabit } & \multicolumn{2}{|c|}{$\begin{array}{l}\text { Separate - } \\
\text { Cohabit }\end{array}$} & \multicolumn{2}{|c|}{ Married } & \multicolumn{2}{|c|}{$\begin{array}{l}\text { Separate - } \\
\text { Married }\end{array}$} \\
\hline & Mean & Std. Dev. & Mean & Std. Dev. & Mean & Std. Dev. & Mean & Std. Dev. \\
\hline \multicolumn{9}{|l|}{ Employment status: } \\
\hline Respondent employed & 0.68 & 0.47 & 0.51 & 0.5 & 0.75 & 0.43 & 0.71 & 0.45 \\
\hline Partner employed & 0.87 & 0.34 & 0.73 & 0.45 & 0.93 & 0.26 & 0.86 & 0.35 \\
\hline \multicolumn{9}{|l|}{ Household finances: } \\
\hline Total weekly family earnings (£) & 333.24 & 305.01 & 226.05 & 231.22 & 412.67 & 331.86 & 358.84 & 306.95 \\
\hline Owner (=1 if owned outright) & 0.04 & 0.2 & 0.03 & 0.17 & 0.1 & 0.3 & 0.04 & 0.2 \\
\hline $\begin{array}{l}\text { Mortgage (=1 if has mortgage against } \\
\text { property) }\end{array}$ & 0.6 & 0.49 & 0.36 & 0.48 & 0.76 & 0.42 & 0.66 & 0.47 \\
\hline Number of saving accounts & 1.21 & 1.36 & 0.76 & 1.04 & 1.85 & 1.57 & 1.3 & 1.38 \\
\hline Value of savings $(£)$ & 5470.84 & 21898.57 & 3521.15 & 35856.45 & 10862.52 & 33461.93 & 5314.87 & 15045.42 \\
\hline We share and manage our finances jointly & 0.5 & 0.5 & 0.38 & 0.49 & 0.52 & 0.5 & 0.46 & 0.5 \\
\hline $\begin{array}{l}\text { Formal credit arrangement }(=1 \text { if has at } \\
\text { least } 1 \text { credit card, charge card or store } \\
\text { card, } 0 \text { otherwise) }\end{array}$ & 0.54 & 0.5 & 0.41 & 0.49 & 0.74 & 0.44 & 0.64 & 0.48 \\
\hline $\begin{array}{l}\text { Formal loan }(=1 \text { if has at least } 1 \text { loan from } \\
\text { a from a Bank, Building Society, finance }\end{array}$ & & & & & & & & \\
\hline company or similar institution, 0 otherwise) & 0.19 & 0.39 & 0.23 & 0.42 & 0.19 & 0.39 & 0.25 & 0.43 \\
\hline \multicolumn{9}{|l|}{$\begin{array}{l}\text { Informal loan ( }=1 \text { if have at least } 1 \text { loan } \\
\text { from a money lender or 'tally man', friend } \\
\text { or relative, a loan, or advance on wages, }\end{array}$} \\
\hline from an employer, 0 otherwise) & 0.12 & 0.32 & 0.21 & 0.41 & 0.06 & 0.23 & 0.13 & 0.33 \\
\hline $\begin{array}{l}\text { Proportion of households who are in arrears } \\
\text { with at least } 1 \mathrm{debt}\end{array}$ & 0.18 & 0.39 & 0.37 & 0.48 & 0.06 & 0.24 & 0.17 & 0.37 \\
\hline Number of debts in arrears (if arrears $>0$ ) & 2.01 & 1.44 & 2.26 & 1.49 & 1.91 & 1.33 & 2.21 & 1.62 \\
\hline Value of outstanding arrears $(£)$ & 109.84 & 493.2 & 215.07 & 710.1 & 38.15 & 321.96 & 137.35 & 679.12 \\
\hline Number of observations (person-year) & \multicolumn{2}{|c|}{8,057} & \multicolumn{2}{|c|}{1,066} & \multicolumn{2}{|c|}{24,303} & \multicolumn{2}{|c|}{1,077} \\
\hline
\end{tabular}


Table 2: Baseline Specification: Discrete-time Proportional Hazard Estimates of the Hazard of Separation

\begin{tabular}{|c|c|c|c|c|}
\hline & \multicolumn{2}{|c|}{ Cohabiting } & \multicolumn{2}{|c|}{ Married } \\
\hline Variable & Coefficient & Hazard Ratio & Coefficient & Hazard Ratio \\
\hline Partnership characteristics: & & & & \\
\hline Respondent's age at the start of the relationship & $\begin{array}{c}-0.026 * * * \\
(0.009)\end{array}$ & $\begin{array}{c}0.975 * * * \\
(0.009)\end{array}$ & $\begin{array}{c}-0.038 * * * \\
(0.013)\end{array}$ & $\begin{array}{c}0.963 * * * \\
(0.013)\end{array}$ \\
\hline Partners have same level of education & $\begin{array}{c}-0.044 \\
(0.100)\end{array}$ & $\begin{array}{c}0.957 \\
(0.096)\end{array}$ & $\begin{array}{l}-0.108 \\
(0.112)\end{array}$ & $\begin{array}{c}0.897 \\
(0.101)\end{array}$ \\
\hline Respondent $5+$ years older than partner & $\begin{array}{l}0.0002 \\
(0.228)\end{array}$ & $\begin{array}{c}1.000 \\
(0.228)\end{array}$ & $\begin{array}{c}0.436 \\
(0.289)\end{array}$ & $\begin{array}{c}1.547 \\
(0.447)\end{array}$ \\
\hline Respondent between 2 and 5 years older than partner & $\begin{array}{c}0.250 \\
(0.180)\end{array}$ & $\begin{array}{c}1.284 \\
(0.231)\end{array}$ & $\begin{array}{c}0.555 * * * \\
(0.213)\end{array}$ & $\begin{array}{c}1.741 * * * \\
(0.372)\end{array}$ \\
\hline Partner 5+ years older than respondent & $\begin{array}{l}-0.023 \\
(0.114)\end{array}$ & $\begin{array}{c}0.977 \\
(0.111)\end{array}$ & $\begin{array}{c}0.060 \\
(0.138)\end{array}$ & $\begin{array}{c}1.062 \\
(0.147)\end{array}$ \\
\hline Child from a previous relationship & $\begin{array}{l}-0.122 \\
(0.136)\end{array}$ & $\begin{array}{c}0.885 \\
(0.120)\end{array}$ & $\begin{array}{c}-0.388 * * \\
(0.155)\end{array}$ & $\begin{array}{c}0.679 * * \\
(0.105)\end{array}$ \\
\hline Previously married & $\begin{array}{l}-0.081 \\
(0.244)\end{array}$ & $\begin{array}{c}0.922 \\
(0.225)\end{array}$ & $\begin{array}{c}0.220 \\
(0.253)\end{array}$ & $\begin{array}{c}1.246 \\
(0.315)\end{array}$ \\
\hline Household characteristics: & & & & \\
\hline Number of dependent children & $\begin{array}{l}-0.051 \\
(0.055)\end{array}$ & $\begin{array}{c}0.950 \\
(0.053)\end{array}$ & $\begin{array}{c}0.197 * * * \\
(0.058)\end{array}$ & $\begin{array}{c}1.218 * * * \\
(0.071)\end{array}$ \\
\hline$=1$ if at least 1 child under the age of 4 years in the household & $\begin{array}{l}-0.001 \\
(0.130)\end{array}$ & $\begin{array}{c}0.999 \\
(0.130)\end{array}$ & $\begin{array}{c}-0.378 * * \\
(0.151)\end{array}$ & $\begin{array}{c}0.685^{* *} \\
(0.103)\end{array}$ \\
\hline Higher degree/Degree - respondent & $\begin{array}{l}-0.287 \\
(0.211)\end{array}$ & $\begin{array}{c}0.750 \\
(0.158)\end{array}$ & $\begin{array}{l}-0.174 \\
(0.162)\end{array}$ & $\begin{array}{c}0.840 \\
(0.136)\end{array}$ \\
\hline Higher degree/Degree - partner & $\begin{array}{l}-0.347 \\
(0.218)\end{array}$ & $\begin{array}{c}0.707 \\
(0.154)\end{array}$ & $\begin{array}{l}-0.129 \\
(0.161)\end{array}$ & $\begin{array}{c}0.879 \\
(0.141)\end{array}$ \\
\hline We share and manage our finances jointly & $\begin{array}{l}-0.393 * * * \\
(0.097)\end{array}$ & $\begin{array}{l}0.675 * * * \\
(0.065)\end{array}$ & $\begin{array}{l}-0.318 * * * \\
(0.106)\end{array}$ & $\begin{array}{c}0.728 * * * \\
(0.077)\end{array}$ \\
\hline Respondent employed & $\begin{array}{l}-0.069 \\
(0.114)\end{array}$ & $\begin{array}{c}0.933 \\
(0.106)\end{array}$ & $\begin{array}{c}0.354 * * * \\
(0.134)\end{array}$ & $\begin{array}{c}1.424 * * * \\
(0.190)\end{array}$ \\
\hline Partner employed & $\begin{array}{c}-0.309 * * \\
(0.131)\end{array}$ & $\begin{array}{c}0.735^{* *} \\
(0.096)\end{array}$ & $\begin{array}{c}-0.424 * * \\
(0.173)\end{array}$ & $\begin{array}{c}0.655^{* *} \\
(0.113)\end{array}$ \\
\hline Total weekly family earnings ( $£^{\prime} 00$ s) & $\begin{array}{l}-0.020 \\
(0.026)\end{array}$ & $\begin{array}{c}0.981 \\
(0.026)\end{array}$ & $\begin{array}{c}0.019 \\
(0.018)\end{array}$ & $\begin{array}{l}1.019 \\
(0.018)\end{array}$ \\
\hline Owner (=1 if owned outright) & $\begin{array}{c}-0.935^{* *} \\
(0.380)\end{array}$ & $\begin{array}{c}0.393 * * \\
(0.149)\end{array}$ & $\begin{array}{c}-0.531 * * \\
(0.257)\end{array}$ & $\begin{array}{c}0.588 * * \\
(0.151)\end{array}$ \\
\hline Mortgage (=1 if has mortgage against property) & $\begin{array}{c}-0.463 * * * \\
(0.122)\end{array}$ & $\begin{array}{c}0.630 * * * \\
(0.077)\end{array}$ & $\begin{array}{c}-0.502 * * * \\
(0.148)\end{array}$ & $\begin{array}{c}0.606 * * * \\
(0.090)\end{array}$ \\
\hline Number of saving accounts & $\begin{array}{l}-0.076 \\
(0.052)\end{array}$ & $\begin{array}{c}0.927 \\
(0.048)\end{array}$ & $\begin{array}{c}-0.159^{* * * *} \\
(0.045)\end{array}$ & $\begin{array}{c}0.853 * * * \\
(0.038)\end{array}$ \\
\hline Number of formal loans & $\begin{array}{c}0.043 \\
(0.113)\end{array}$ & $\begin{array}{c}1.043 \\
(0.118)\end{array}$ & $\begin{array}{c}0.043 \\
(0.118)\end{array}$ & $\begin{array}{c}1.044 \\
(0.124)\end{array}$ \\
\hline Number of debts in arrears & $\begin{array}{l}0.074 * \\
(0.041)\end{array}$ & $\begin{array}{l}1.077 * \\
(0.044)\end{array}$ & $\begin{array}{c}0.228 * * * \\
(0.055)\end{array}$ & $\begin{array}{c}1.256 * * * \\
(0.070)\end{array}$ \\
\hline Duration Dependence: & & & & \\
\hline$=1$ if relationship lasted 2 years, 0 otherwise & $\begin{array}{c}-0.492 * * * \\
(0.158)\end{array}$ & $\begin{array}{c}0.611 * * * \\
(0.097)\end{array}$ & $\begin{array}{l}-0.164 \\
(0.395)\end{array}$ & $\begin{array}{c}0.849 \\
(0.335)\end{array}$ \\
\hline$=1$ if relationship lasted 3 years, 0 otherwise & $\begin{array}{l}-0.253 \\
(0.159)\end{array}$ & $\begin{array}{c}0.777 \\
(0.123)\end{array}$ & $\begin{array}{l}-0.364 \\
(0.402)\end{array}$ & $\begin{array}{c}0.695 \\
(0.280)\end{array}$ \\
\hline$=1$ if relationship lasted 4 years, 0 otherwise & $\begin{array}{l}-0.513 * * * \\
(0.187)\end{array}$ & $\begin{array}{c}0.599 * * * \\
(0.112)\end{array}$ & $\begin{array}{l}-0.049 \\
(0.364)\end{array}$ & $\begin{array}{c}0.952 \\
(0.347)\end{array}$ \\
\hline$=1$ if relationship lasted 5 years, 0 otherwise & $\begin{array}{l}-0.800 * * * \\
(0.223)\end{array}$ & $\begin{array}{c}0.449 * * * \\
(0.100)\end{array}$ & $\begin{array}{l}-0.010 \\
(0.363)\end{array}$ & $\begin{array}{c}0.990 \\
(0.359)\end{array}$ \\
\hline$=1$ if relationship lasted between 6 and 10 years, 0 otherwise & $\begin{array}{l}-0.793 * * * \\
(0.170)\end{array}$ & $\begin{array}{c}0.452 * * * \\
(0.077)\end{array}$ & $\begin{array}{l}-0.346 \\
(0.316)\end{array}$ & $\begin{array}{c}0.708 \\
(0.224)\end{array}$ \\
\hline$=1$ if relationship lasted between 11 and 15 years, 0 otherwise & $\begin{array}{l}-1.072 * * * \\
(0.269)\end{array}$ & $\begin{array}{c}0.342 * * * \\
(0.092)\end{array}$ & $\begin{array}{l}-0.501 \\
(0.335)\end{array}$ & $\begin{array}{c}0.606 \\
(0.203)\end{array}$ \\
\hline$=1$ if relationship lasted more than 15 years, 0 otherwise & $\begin{array}{l}-1.212 * * * \\
(0.321)\end{array}$ & $\begin{array}{c}0.298 * * * \\
(0.095)\end{array}$ & $\begin{array}{c}-1.005^{* * *} \\
(0.355)\end{array}$ & $\begin{array}{c}0.366^{* * *} \\
(0.130)\end{array}$ \\
\hline Constant & $\begin{array}{c}-0.904 * * * \\
(0.335) \\
\end{array}$ & $\begin{array}{c}0.405 * * * \\
(0.136) \\
\end{array}$ & $\begin{array}{c}-2.323 * * * \\
(0.600) \\
\end{array}$ & $\begin{array}{c}0.098 * * * \\
(0.059) \\
\end{array}$ \\
\hline $\begin{array}{l}\text { Number of observations } \\
\text { Log-likelihood }\end{array}$ & & & & \\
\hline
\end{tabular}


Table 3: Sensitivity Analysis: The Effect Alternative Measures of Arrears and Financial Strain have on Separation

\begin{tabular}{|c|c|c|c|c|}
\hline \multirow[b]{2}{*}{ Variable } & \multicolumn{2}{|c|}{ Cohabiting } & \multicolumn{2}{|c|}{ Married } \\
\hline & Coefficient & $\begin{array}{c}\text { Hazard } \\
\text { Ratio }\end{array}$ & Coefficient & $\begin{array}{c}\text { Hazard } \\
\text { Ratio }\end{array}$ \\
\hline \multicolumn{5}{|l|}{ (1) Value of Arrears } \\
\hline Number of formal loans & $\begin{array}{c}0.052 \\
(0.112)\end{array}$ & $\begin{array}{c}1.054 \\
(0.118)\end{array}$ & $\begin{array}{c}0.044 \\
(0.119)\end{array}$ & $\begin{array}{c}1.045 \\
(0.125)\end{array}$ \\
\hline$=1$ if arrears $>£ 0$ and arrears $<=£ 500$ & $\begin{array}{l}0.204^{*} \\
(0.128)\end{array}$ & $\begin{array}{l}1.226 \\
(0.157)\end{array}$ & $\begin{array}{c}0.164 \\
(0.205)\end{array}$ & $\begin{array}{c}1.178 \\
(0.241)\end{array}$ \\
\hline$=1$ if arrears $>£ 500$ and arrears $<=£ 1000$ & $\begin{array}{l}0.369^{*} \\
(0.202)\end{array}$ & $\begin{array}{l}1.447 * \\
(0.292)\end{array}$ & $\begin{array}{c}0.425 \\
(0.336)\end{array}$ & $\begin{array}{c}1.529 \\
(0.514)\end{array}$ \\
\hline$=1$ if arrears $>£ 1000$ and arrears $<=£ 2000$ & $\begin{array}{c}0.244 \\
(0.258)\end{array}$ & $\begin{array}{c}1.276 \\
(0.330)\end{array}$ & $\begin{array}{l}0.908 * * * \\
(0.342)\end{array}$ & $\begin{array}{c}2.479 * * * \\
(0.847)\end{array}$ \\
\hline$=1$ if arrears $>£ 2000$ & $\begin{array}{c}0.136 \\
(0.338)\end{array}$ & $\begin{array}{c}1.146 \\
(0.388)\end{array}$ & $\begin{array}{l}0.860 * * \\
(0.432)\end{array}$ & $\begin{array}{r}2.362 * * \\
(1.021)\end{array}$ \\
\hline Additional controls & \multicolumn{2}{|c|}{ Yes } & \multicolumn{2}{|c|}{ Yes } \\
\hline $\begin{array}{l}\text { Number of observations } \\
\text { Log-likelihood }\end{array}$ & \multicolumn{2}{|c|}{$\begin{array}{l}9,123 \\
-1810\end{array}$} & \multicolumn{2}{|c|}{-2070} \\
\hline \multicolumn{5}{|l|}{ (2) Formal + Informal Loans } \\
\hline Number of formal loans & $\begin{array}{c}0.049 \\
(0.113)\end{array}$ & $\begin{array}{c}1.051 \\
(0.118)\end{array}$ & $\begin{array}{c}0.045 \\
(0.119)\end{array}$ & $\begin{array}{c}1.046 \\
(0.124)\end{array}$ \\
\hline Number of informal loans & $\begin{array}{l}0.103 \\
(0.109)\end{array}$ & $\begin{array}{c}1.108 \\
(0.120)\end{array}$ & $\begin{array}{c}0.315 * * \\
(0.154)\end{array}$ & $\begin{array}{l}1.370 * * \\
(0.211)\end{array}$ \\
\hline Number of debts in arrears & $\begin{array}{c}0.058 \\
(0.039)\end{array}$ & $\begin{array}{c}1.059 \\
(0.041)\end{array}$ & $\begin{array}{c}0.176^{* * * *} \\
(0.055)\end{array}$ & $\begin{array}{c}1.192^{* * * *} \\
(0.066)\end{array}$ \\
\hline Additional controls & \multicolumn{2}{|c|}{ Yes } & \multicolumn{2}{|c|}{ Yes } \\
\hline $\begin{array}{l}\text { Number of observations } \\
\text { Log-likelihood }\end{array}$ & \multicolumn{2}{|c|}{$\begin{array}{l}9,123 \\
-1815\end{array}$} & \multicolumn{2}{|c|}{25,380} \\
\hline \multicolumn{5}{|l|}{ (3) Value of Loans (Debt to Earnings Ratio) } \\
\hline Ratio of debt/earnings & $\begin{array}{l}-0.002 \\
(0.003)\end{array}$ & $\begin{array}{c}0.998 \\
(0.003)\end{array}$ & $\begin{array}{c}0.001 * * \\
(0.000)\end{array}$ & $\begin{array}{l}1.001 * * \\
(0.000)\end{array}$ \\
\hline Number of debts in arrears & $\begin{array}{l}0.095^{*} \\
(0.055)\end{array}$ & $\begin{array}{l}1.100 * \\
(0.060)\end{array}$ & $\begin{array}{l}0.240 * * * \\
(0.078)\end{array}$ & $\begin{array}{c}1.271 * * * \\
(0.099)\end{array}$ \\
\hline Additional controls & \multicolumn{2}{|c|}{ Yes } & \multicolumn{2}{|c|}{ Yes } \\
\hline $\begin{array}{l}\text { Number of observations } \\
\text { Log-likelihood }\end{array}$ & \multicolumn{2}{|c|}{$\begin{array}{l}6,556 \\
-1184 \\
\end{array}$} & \multicolumn{2}{|c|}{$\begin{array}{l}18,669 \\
-1396 \\
\end{array}$} \\
\hline \multirow{2}{*}{$\begin{array}{l}\text { (4) Lagged Arrears } \\
\text { Number of formal loans }\end{array}$} & & & & \\
\hline & $\begin{array}{l}0.115 \\
(0.139)\end{array}$ & $\begin{array}{c}1.121 \\
(0.156)\end{array}$ & $\begin{array}{l}-0.100 \\
(0.163)\end{array}$ & $\begin{array}{c}0.905 \\
(0.148)\end{array}$ \\
\hline Number of debts in arrears & $\begin{array}{c}0.167 * * * \\
(0.054)\end{array}$ & $\begin{array}{c}1.181 * * * \\
(0.064)\end{array}$ & $\begin{array}{l}0.211 * * * \\
(0.081)\end{array}$ & $\begin{array}{c}1.234 * * * \\
(0.101)\end{array}$ \\
\hline Number of debts in arrears in $\mathrm{t}-1$ & $\begin{array}{l}-0.060 \\
(0.064)\end{array}$ & $\begin{array}{c}0.941 \\
(0.060)\end{array}$ & $\begin{array}{l}-0.065 \\
(0.102)\end{array}$ & $\begin{array}{c}0.937 \\
(0.096)\end{array}$ \\
\hline Number of debts in arrears in $\mathrm{t}-2$ & $\begin{array}{c}0.001 \\
(0.056)\end{array}$ & $\begin{array}{c}1.001 \\
(0.056)\end{array}$ & $\begin{array}{c}0.117 \\
(0.082)\end{array}$ & $\begin{array}{l}1.124 \\
(0.093)\end{array}$ \\
\hline Additional controls & & & & \\
\hline $\begin{array}{l}\text { Number of observations } \\
\text { Log-likelihood }\end{array}$ & & & & \\
\hline (5) Persistent Arrears & & & & \\
\hline Number of formal loans & $\begin{array}{c}0.113 \\
(0.139)\end{array}$ & $\begin{array}{c}1.119 \\
(0.156)\end{array}$ & $\begin{array}{l}-0.095 \\
(0.163)\end{array}$ & $\begin{array}{c}0.910 \\
(0.148)\end{array}$ \\
\hline Number of debts in arrears & $\begin{array}{c}0.140 * * * \\
(0.052)\end{array}$ & $\begin{array}{c}1.151 * * * \\
(0.060)\end{array}$ & $\begin{array}{l}0.196 * * \\
(0.079)\end{array}$ & $\begin{array}{l}1.217 * * \\
(0.096)\end{array}$ \\
\hline Positive arrears in $\mathrm{t}-1$ and $\mathrm{t}-2$ & $\begin{array}{c}0.012 \\
(0.161)\end{array}$ & $\begin{array}{l}1.012 \\
(0.163)\end{array}$ & $\begin{array}{c}0.229 \\
(0.257)\end{array}$ & $\begin{array}{l}1.258 \\
(0.323)\end{array}$ \\
\hline Additional controls & & & & \\
\hline $\begin{array}{l}\text { Number of observations } \\
\text { Log-likelihood }\end{array}$ & & & & \\
\hline
\end{tabular}


Table 4a: Sensitivity Analysis: Endogeneity - Omitted Variables (I)

\begin{tabular}{|c|c|c|c|c|}
\hline & \multicolumn{2}{|c|}{ Cohabiting } & \multicolumn{2}{|c|}{ Married } \\
\hline Variable & Coefficient & $\begin{array}{c}\text { Hazard } \\
\text { Ratio }\end{array}$ & Coefficient & $\begin{array}{c}\text { Hazard } \\
\text { Ratio }\end{array}$ \\
\hline \multicolumn{5}{|l|}{ (1) Shocks to Income (between $t-1$ and $t$ ) } \\
\hline Number of debts in arrears & $\begin{array}{l}0.117 * * \\
(0.055)\end{array}$ & $\begin{array}{l}1.125 * * \\
(0.062)\end{array}$ & $\begin{array}{c}0.271 * * * \\
(0.066)\end{array}$ & $\begin{array}{c}1.311 * * * \\
(0.087)\end{array}$ \\
\hline Change in household income between $\mathrm{t}-1$ and $\mathrm{t}$ & $\begin{array}{c}0.033 \\
(0.036)\end{array}$ & $\begin{array}{c}1.033 \\
(0.037)\end{array}$ & $\begin{array}{c}0.018 \\
(0.026)\end{array}$ & $\begin{array}{c}1.018 \\
(0.026)\end{array}$ \\
\hline Additional controls & \multicolumn{2}{|c|}{ Yes } & \multicolumn{2}{|c|}{ Yes } \\
\hline $\begin{array}{l}\text { Number of observations } \\
\text { Log-likelihood }\end{array}$ & \multicolumn{2}{|c|}{$\begin{array}{l}6,835 \\
-1166\end{array}$} & 21,822 & \\
\hline \multicolumn{5}{|c|}{ (2) Shocks to Family Circumstances (between t-1 and t) } \\
\hline Number of debts in arrears & $\begin{array}{r}0.113 * * \\
(0.055)\end{array}$ & $\begin{array}{l}1.119 * * \\
(0.061)\end{array}$ & $\begin{array}{l}0.270 * * * \\
(0.066)\end{array}$ & $\begin{array}{l}1.310 * * * \\
(0.087)\end{array}$ \\
\hline Respondent leaves the labour market & $\begin{array}{c}0.114 \\
(0.250)\end{array}$ & $\begin{array}{c}1.121 \\
(0.280)\end{array}$ & $\begin{array}{c}0.437 \\
(0.285)\end{array}$ & $\begin{array}{c}1.548 \\
(0.442)\end{array}$ \\
\hline Partner leaves the labour market & $\begin{array}{l}-0.026 \\
(0.326)\end{array}$ & $\begin{array}{c}0.975 \\
(0.318)\end{array}$ & $\begin{array}{l}-0.219 \\
(0.366)\end{array}$ & $\begin{array}{c}0.803 \\
(0.294)\end{array}$ \\
\hline Deterioration in respondent's health & $\begin{array}{l}-0.163 \\
(0.462)\end{array}$ & $\begin{array}{c}0.850 \\
(0.393)\end{array}$ & $\begin{array}{l}0.625 * \\
(0.338)\end{array}$ & $\begin{array}{l}1.868 * \\
(0.631)\end{array}$ \\
\hline Birth of child & $\begin{array}{l}-0.562 * * \\
(0.242)\end{array}$ & $\begin{array}{l}0.570 * * \\
(0.138)\end{array}$ & $\begin{array}{l}-0.489 * \\
(0.287)\end{array}$ & $\begin{array}{l}0.613^{*} \\
(0.176)\end{array}$ \\
\hline Additional controls & \multicolumn{2}{|c|}{ Yes } & \multicolumn{2}{|c|}{ Yes } \\
\hline $\begin{array}{l}\text { Number of observations } \\
\text { Log-likelihood }\end{array}$ & \multicolumn{2}{|c|}{$\begin{array}{l}6,835 \\
-1163\end{array}$} & \multicolumn{2}{|c|}{$\begin{array}{c}21,822 \\
-1733\end{array}$} \\
\hline \multicolumn{5}{|c|}{$\begin{array}{l}\text { Notes: Standard errors in parentheses; } * * * \mathrm{p}<0.01, * * \mathrm{p}<0.05, * \mathrm{p}<0.1 \text {. Additional controls for all regressions } \\
\text { are the same as in Table } 2 \text {. The survey collects insufficient data on the male partner to capture changes in his } \\
\text { health. }\end{array}$} \\
\hline
\end{tabular}


Table 5: Sensitivity Analysis: Endogeneity - Two-stage Probit

\begin{tabular}{|c|c|c|}
\hline & Cohabiting & Married \\
\hline Variable & Coefficient & Coefficient \\
\hline Respondent's age at the start of the relationship & $\begin{array}{c}-0.013 * * \\
(0.005)\end{array}$ & $\begin{array}{c}-0.020 * * * \\
(0.006)\end{array}$ \\
\hline Partners have same level of education & $\begin{array}{c}0.033 \\
(0.058)\end{array}$ & $\begin{array}{l}-0.016 \\
(0.047)\end{array}$ \\
\hline Respondent $5+$ years older than partner & $\begin{array}{l}-0.013 \\
(0.132)\end{array}$ & $\begin{array}{c}0.163 \\
(0.120)\end{array}$ \\
\hline Respondent between 2 and 5 years older than partner & $\begin{array}{c}0.106 \\
(0.105)\end{array}$ & $\begin{array}{l}0.165^{*} \\
(0.090)\end{array}$ \\
\hline Partner 5+ years older than respondent & $\begin{array}{c}0.052 \\
(0.065)\end{array}$ & $\begin{array}{l}-0.012 \\
(0.057)\end{array}$ \\
\hline Child from a previous relationship & $\begin{array}{l}-0.015 \\
(0.077)\end{array}$ & $\begin{array}{l}-0.092 \\
(0.062)\end{array}$ \\
\hline Previously married & $\begin{array}{c}0.014 \\
(0.121)\end{array}$ & $\begin{array}{c}0.126 \\
(0.103)\end{array}$ \\
\hline Number of dependent children & $\begin{array}{l}-0.040 \\
(0.033)\end{array}$ & $\begin{array}{c}0.059 * * \\
(0.025)\end{array}$ \\
\hline$=1$ if at least 1 child under the age of 4 years in the household & $\begin{array}{l}-0.074 \\
(0.074)\end{array}$ & $\begin{array}{c}-0.205^{* * *} \\
(0.064)\end{array}$ \\
\hline Higher degree/Degree - respondent & $\begin{array}{l}-0.084 \\
(0.109)\end{array}$ & $\begin{array}{l}-0.042 \\
(0.064)\end{array}$ \\
\hline Higher degree/Degree - partner & $\begin{array}{l}-0.036 \\
(0.107)\end{array}$ & $\begin{array}{l}-0.040 \\
(0.065)\end{array}$ \\
\hline We share and manage our finances jointly & $\begin{array}{c}-0.219 * * * \\
(0.057)\end{array}$ & $\begin{array}{c}-0.109 * * \\
(0.044)\end{array}$ \\
\hline Respondent employed & $\begin{array}{l}-0.049 \\
(0.067)\end{array}$ & $\begin{array}{c}0.131 * * \\
(0.057)\end{array}$ \\
\hline Partner employed & $\begin{array}{l}-0.039 \\
(0.088)\end{array}$ & $\begin{array}{c}-0.246 * * * \\
(0.078)\end{array}$ \\
\hline Total weekly family earnings ( $\left.£^{\prime} 00 s\right)$ & $\begin{array}{c}0.000 \\
(0.013)\end{array}$ & $\begin{array}{c}0.012 \\
(0.007)\end{array}$ \\
\hline Owner (=1 if owned outright) & $\begin{array}{c}-0.224 \\
(0.176)\end{array}$ & $\begin{array}{l}-0.109 \\
(0.108)\end{array}$ \\
\hline Mortgage ( $=1$ if has mortgage against property) & $\begin{array}{c}-0.176 * * \\
(0.075)\end{array}$ & $\begin{array}{c}-0.125^{*} \\
(0.071)\end{array}$ \\
\hline Number of saving accounts & $\begin{array}{c}-0.037 \\
(0.029)\end{array}$ & $\begin{array}{c}-0.043 * * \\
(0.018)\end{array}$ \\
\hline Number of formal loans & $\begin{array}{c}0.023 \\
(0.069)\end{array}$ & $\begin{array}{c}0.009 \\
(0.053)\end{array}$ \\
\hline Number of debts in arrears & $\begin{array}{c}0.237 * * \\
(0.101)\end{array}$ & $\begin{array}{c}0.269 * * \\
(0.121)\end{array}$ \\
\hline Constant & $\begin{array}{c}-0.798^{* * * *} \\
(0.238)\end{array}$ & $\begin{array}{c}-0.965^{* * * *} \\
(0.243) \\
\end{array}$ \\
\hline Number of observations & 6,835 & 21,822 \\
\hline Test of overidentifying restrictions (p-value): & 0.779 & 0.537 \\
\hline \multicolumn{3}{|c|}{$\begin{array}{l}\text { Notes: Standard errors in parentheses; } * * * \mathrm{p}<0.01, * * \mathrm{p}<0.05, * \mathrm{p}<0.1 \text {. Regressions also include } \\
\text { controls for duration of relationship. Instruments for over-indebtedness include: having a prepayment } \\
\text { electricity meter; being unable to afford: two pairs of all-weather shoes for each adult; a celebration with } \\
\text { presents for friends and family at special occasions like birthdays; a one-week holiday away from home, } \\
\text { not staying with relatives; a night out once a month; a car/var. }\end{array}$} \\
\hline
\end{tabular}


Table 6: Symmetry of Shocks

\begin{tabular}{|c|c|c|c|c|c|c|c|c|}
\hline \multirow[b]{2}{*}{ Variable } & \multicolumn{2}{|c|}{ Cohabiting } & \multicolumn{2}{|c|}{ Married } & \multicolumn{2}{|c|}{ Cohabiting } & \multicolumn{2}{|c|}{ Married } \\
\hline & Coefficient & $\begin{array}{l}\text { Hazard } \\
\text { Ratio }\end{array}$ & Coefficient & $\begin{array}{l}\text { Hazard } \\
\text { Ratio }\end{array}$ & Coefficient & $\begin{array}{c}\text { Hazard } \\
\text { Ratio }\end{array}$ & Coefficient & $\begin{array}{l}\text { Hazard } \\
\text { Ratio }\end{array}$ \\
\hline $\begin{array}{l}\text { Increase in the number } \\
\text { of savings accounts }\end{array}$ & $\begin{array}{l}-0.194 \\
(0.159)\end{array}$ & $\begin{array}{c}0.824 \\
(0.131)\end{array}$ & $\begin{array}{l}-0.211 \\
(0.143)\end{array}$ & $\begin{array}{c}0.810 \\
(0.116)\end{array}$ & $\begin{array}{l}-0.192 \\
(0.159)\end{array}$ & $\begin{array}{c}0.826 \\
(0.131)\end{array}$ & $\begin{array}{l}-0.214 \\
(0.142)\end{array}$ & $\begin{array}{c}0.808 \\
(0.115)\end{array}$ \\
\hline $\begin{array}{l}\text { Decrease in the number } \\
\text { of savings accounts }\end{array}$ & $\begin{array}{c}0.076 \\
(0.147)\end{array}$ & $\begin{array}{l}1.079 \\
(0.159)\end{array}$ & $\begin{array}{c}0.020 \\
(0.134)\end{array}$ & $\begin{array}{l}1.020 \\
(0.137)\end{array}$ & $\begin{array}{c}0.082 \\
(0.147)\end{array}$ & $\begin{array}{l}1.085 \\
(0.160)\end{array}$ & $\begin{array}{c}0.031 \\
(0.134)\end{array}$ & $\begin{array}{c}1.032 \\
(0.138)\end{array}$ \\
\hline Takes out a mortgage & $\begin{array}{l}-0.001 \\
(0.349)\end{array}$ & $\begin{array}{c}0.999 \\
(0.349)\end{array}$ & $\begin{array}{c}0.078 \\
(0.383)\end{array}$ & $\begin{array}{l}1.081 \\
(0.413)\end{array}$ & $\begin{array}{c}0.007 \\
(0.349)\end{array}$ & $\begin{array}{l}1.007 \\
(0.351)\end{array}$ & $\begin{array}{c}0.089 \\
(0.380)\end{array}$ & $\begin{array}{l}1.093 \\
(0.416)\end{array}$ \\
\hline $\begin{array}{l}\text { No longer has a } \\
\text { mortgage }\end{array}$ & $\begin{array}{l}-1.585 \\
(1.008)\end{array}$ & $\begin{array}{l}0.205 \\
(0.206)\end{array}$ & $\begin{array}{l}0.318 \\
(0.328)\end{array}$ & $\begin{array}{l}1.375 \\
(0.451)\end{array}$ & $\begin{array}{l}-1.577 \\
(1.007)\end{array}$ & $\begin{array}{c}0.207 \\
(0.208)\end{array}$ & $\begin{array}{c}0.310 \\
(0.327)\end{array}$ & $\begin{array}{c}1.363 \\
(0.446)\end{array}$ \\
\hline $\begin{array}{l}\text { Increase in the number } \\
\text { of formal loans } \\
\text { outstanding }\end{array}$ & $\begin{array}{c}0.009 \\
(0.195)\end{array}$ & $\begin{array}{c}1.009 \\
(0.197)\end{array}$ & $\begin{array}{l}-0.014 \\
(0.189)\end{array}$ & $\begin{array}{c}0.986 \\
(0.186)\end{array}$ & $\begin{array}{c}0.015 \\
(0.195)\end{array}$ & $\begin{array}{l}1.015 \\
(0.197)\end{array}$ & $\begin{array}{l}-0.018 \\
(0.188)\end{array}$ & $\begin{array}{c}0.982 \\
(0.184)\end{array}$ \\
\hline $\begin{array}{l}\text { Decrease in the number } \\
\text { of formal loans } \\
\text { outstanding }\end{array}$ & $\begin{array}{l}0.292^{*} \\
(0.161)\end{array}$ & $\begin{array}{l}1.339^{*} \\
(0.216)\end{array}$ & $\begin{array}{c}0.224 \\
(0.155)\end{array}$ & $\begin{array}{l}1.251 \\
(0.194)\end{array}$ & $\begin{array}{l}0.296^{*} \\
(0.162)\end{array}$ & $\begin{array}{l}1.345^{*} \\
(0.217)\end{array}$ & $\begin{array}{c}0.226 \\
(0.154)\end{array}$ & $\begin{array}{c}1.253 \\
(0.193)\end{array}$ \\
\hline $\begin{array}{l}\text { Increase in the number } \\
\text { of debts in arrears }\end{array}$ & $\begin{array}{c}0.655 * * * \\
(0.170)\end{array}$ & $\begin{array}{c}1.925 * * * \\
(0.328)\end{array}$ & $\begin{array}{c}0.654 * * * \\
(0.213)\end{array}$ & $\begin{array}{c}1.923 * * * \\
(0.409)\end{array}$ & $\begin{array}{c}0.633 * * * \\
(0.171)\end{array}$ & $\begin{array}{c}1.884 * * * \\
(0.322)\end{array}$ & $\begin{array}{c}0.638^{* * * *} \\
(0.211)\end{array}$ & $\begin{array}{c}1.893 * * * \\
(0.399)\end{array}$ \\
\hline $\begin{array}{l}\text { Decrease in the number } \\
\text { of debts in arrears }\end{array}$ & $\begin{array}{c}0.535 * * * \\
(0.164)\end{array}$ & $\begin{array}{c}1.707 * * * \\
(0.281)\end{array}$ & $\begin{array}{l}-0.117 \\
(0.251)\end{array}$ & $\begin{array}{c}0.890 \\
(0.223)\end{array}$ & $\begin{array}{c}0.519 * * * \\
(0.165)\end{array}$ & $\begin{array}{c}1.680 * * * \\
(0.277)\end{array}$ & $\begin{array}{l}-0.140 \\
(0.250)\end{array}$ & $\begin{array}{c}0.869 \\
(0.217)\end{array}$ \\
\hline $\begin{array}{l}\text { Respondent enters the } \\
\text { labour market }\end{array}$ & & & & & $\begin{array}{l}0.260 \\
(0.228)\end{array}$ & $\begin{array}{l}1.297 \\
(0.295)\end{array}$ & $\begin{array}{l}-0.053 \\
(0.238)\end{array}$ & $\begin{array}{c}0.949 \\
(0.226)\end{array}$ \\
\hline $\begin{array}{l}\text { Respondent leaves the } \\
\text { labour market }\end{array}$ & & & & & $\begin{array}{c}0.039 \\
(0.248)\end{array}$ & $\begin{array}{l}1.040 \\
(0.258)\end{array}$ & $\begin{array}{c}0.335 \\
(0.279)\end{array}$ & $\begin{array}{c}1.398 \\
(0.390)\end{array}$ \\
\hline $\begin{array}{l}\text { Partner enters the labour } \\
\text { market }\end{array}$ & & & & & $\begin{array}{c}0.191 \\
(0.301)\end{array}$ & $\begin{array}{l}1.211 \\
(0.365)\end{array}$ & $\begin{array}{c}0.754^{* *} \\
(0.296)\end{array}$ & $\begin{array}{c}2.126^{* *} \\
(0.629)\end{array}$ \\
\hline $\begin{array}{l}\text { Partner leaves the labour } \\
\text { market }\end{array}$ & & & & & $\begin{array}{l}-0.069 \\
(0.327)\end{array}$ & $\begin{array}{c}0.933 \\
(0.305)\end{array}$ & $\begin{array}{l}-0.335 \\
(0.358)\end{array}$ & $\begin{array}{c}0.716 \\
(0.256)\end{array}$ \\
\hline $\begin{array}{l}\text { Deterioration in } \\
\text { respondent's health }\end{array}$ & & & & & $\begin{array}{l}-0.152 \\
(0.462)\end{array}$ & $\begin{array}{c}0.859 \\
(0.396)\end{array}$ & $\begin{array}{l}0.679 * * \\
(0.334)\end{array}$ & $\begin{array}{l}1.971 * * \\
(0.658)\end{array}$ \\
\hline $\begin{array}{l}\text { Improvement in } \\
\text { respondent's health }\end{array}$ & & & & & $\begin{array}{r}-0.154 \\
(0.463) \\
\end{array}$ & $\begin{array}{c}0.857 \\
(0.397)\end{array}$ & $\begin{array}{r}0.254 \\
(0.395)\end{array}$ & $\begin{array}{c}1.289 \\
(0.509)\end{array}$ \\
\hline $\begin{array}{l}\text { Number of observations } \\
\text { Log-likelihood }\end{array}$ & $\begin{array}{l}6,83 \\
-116\end{array}$ & & $\begin{array}{c}21,8 \\
-17\end{array}$ & & $\begin{array}{l}6,8 \\
-11\end{array}$ & & & \\
\hline
\end{tabular}


Table 7: Planning for Separation - Changes to Labour Supply (Married Couples)

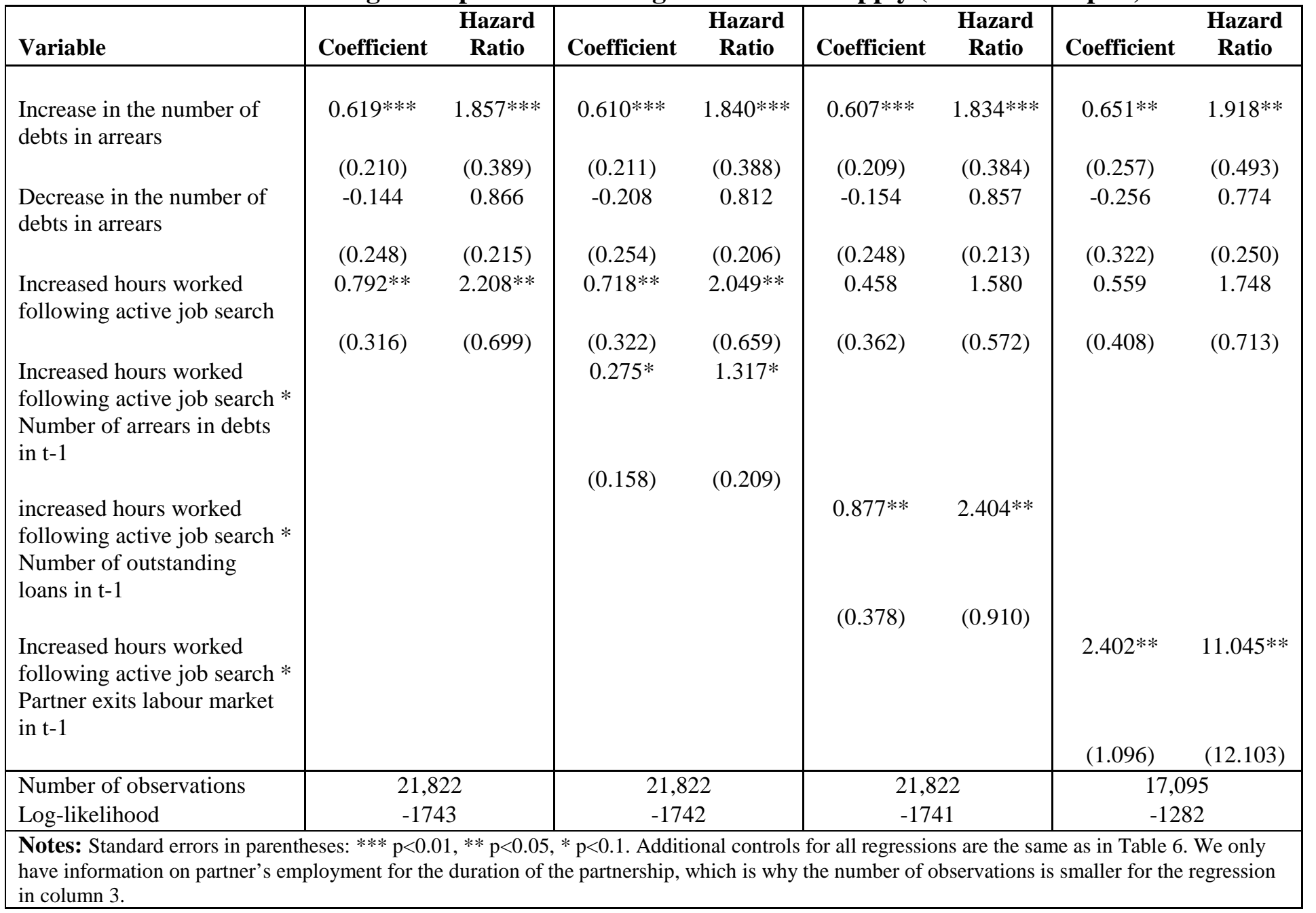


Table 8: Relationship Strain and Separation

\begin{tabular}{|c|c|c|c|c|}
\hline & \multicolumn{2}{|l|}{ Cohabiting } & \multicolumn{2}{|l|}{ Married } \\
\hline Variable & Coefficient & $\begin{array}{c}\text { Hazard } \\
\text { Ratio }\end{array}$ & Coefficient & $\begin{array}{c}\text { Hazard } \\
\text { Ratio }\end{array}$ \\
\hline \multicolumn{5}{|l|}{ (1) Active job search } \\
\hline Increase in the number of debts in arrears & $\begin{array}{l}0.627 * * * \\
(0.167)\end{array}$ & $\begin{array}{l}1.872 * * * \\
(0.313)\end{array}$ & $\begin{array}{l}0.554 * * * \\
(0.208)\end{array}$ & $\begin{array}{l}1.739 * * * \\
(0.362)\end{array}$ \\
\hline Decrease in the number of debts in arrears & $\begin{array}{c}0.518 * * * \\
(0.161)\end{array}$ & $\begin{array}{c}1.678 * * * \\
(0.271)\end{array}$ & $\begin{array}{l}-0.172 \\
(0.248)\end{array}$ & $\begin{array}{c}0.842 \\
(0.209)\end{array}$ \\
\hline Lived apart from partner/spouse in last 12 months & $\begin{array}{c}1.730 * * * \\
(0.286)\end{array}$ & $\begin{array}{c}5.639 * * * \\
(1.615)\end{array}$ & $\begin{array}{c}2.157 * * * \\
(0.454)\end{array}$ & $\begin{array}{c}8.643 * * * \\
(3.920)\end{array}$ \\
\hline Increased hours worked following active job search & $\begin{array}{l}-0.411 \\
(0.333)\end{array}$ & $\begin{array}{c}0.663 \\
(0.221)\end{array}$ & $\begin{array}{l}0.812 * * * \\
(0.257)\end{array}$ & $\begin{array}{l}2.253 * * * \\
(0.579)\end{array}$ \\
\hline \multirow[t]{2}{*}{$\begin{array}{l}\text { Lived part from partner/spouse in last } 12 \\
\text { months*Increased households worked following active } \\
\text { job search }\end{array}$} & -0.424 & 0.654 & -0.019 & 0.981 \\
\hline & \multicolumn{2}{|c|}{ Yes } & \multicolumn{2}{|c|}{ Yes } \\
\hline $\begin{array}{l}\text { Number of observations } \\
\text { Log-likelihood }\end{array}$ & \multicolumn{2}{|c|}{$\begin{array}{l}6,835 \\
-1149 \\
\end{array}$} & \multicolumn{2}{|c|}{$\begin{array}{c}21,822 \\
-1730\end{array}$} \\
\hline \multicolumn{5}{|l|}{ (2) Number of debts in arrears } \\
\hline Increase in the number of debts in arrears & $\begin{array}{c}0.639 * * * \\
(0.168)\end{array}$ & $\begin{array}{c}1.895^{* * * *} \\
(0.317)\end{array}$ & $\begin{array}{c}0.631 * * * \\
(0.211)\end{array}$ & $\begin{array}{c}1.879 * * * \\
(0.396)\end{array}$ \\
\hline Decrease in the number of debts in arrears & $\begin{array}{l}0.511 * * * \\
(0.162)\end{array}$ & $\begin{array}{l}1.667 * * * \\
(0.269)\end{array}$ & $\begin{array}{l}-0.156 \\
(0.250)\end{array}$ & $\begin{array}{c}0.855 \\
(0.214)\end{array}$ \\
\hline Lived apart from partner/spouse in last 12 months & $\begin{array}{l}1.949 * * * \dagger \\
(0.343)\end{array}$ & $\begin{array}{l}7.021 * * * \\
(2.405)\end{array}$ & $\begin{array}{l}2.543 * * * \dagger \\
\quad(0.470)\end{array}$ & $\begin{array}{l}12.721 * * * \\
(5.983)\end{array}$ \\
\hline \multirow[t]{2}{*}{$\begin{array}{l}\text { Lived apart from partner/spouse in last } 12 \\
\text { months*Number of debts in arrears }\end{array}$} & $-0.237 \dagger$ & 0.789 & $-0.300 \dagger$ & 0.741 \\
\hline & $(0.215)$ & $(0.169)$ & $(0.221)$ & $(0.164)$ \\
\hline Additional controls & \multicolumn{2}{|c|}{ Yes } & \multicolumn{2}{|c|}{ Yes } \\
\hline $\begin{array}{l}\text { Number of observations } \\
\text { Log-likelihood }\end{array}$ & \multicolumn{2}{|c|}{$\begin{array}{r}6,835 \\
-1149 \\
\end{array}$} & \multicolumn{2}{|c|}{$\begin{array}{c}21,822 \\
-1734\end{array}$} \\
\hline \multirow{2}{*}{$\begin{array}{l}\text { (3) Number of formal loans } \\
\text { Increase in the number of debts in arrears }\end{array}$} & & & & \\
\hline & $\begin{array}{l}0.615^{* * *} * \\
(0.167)\end{array}$ & $\begin{array}{l}1.849 * * * \\
(0.309)\end{array}$ & $\begin{array}{l}0.596 * * * \\
(0.210)\end{array}$ & $\begin{array}{l}1.814 * * * \\
(0.381)\end{array}$ \\
\hline Decrease in the number of debts in arrears & $\begin{array}{l}0.503 * * * \\
(0.161)\end{array}$ & $\begin{array}{l}1.654 * * * \\
(0.267)\end{array}$ & $\begin{array}{l}-0.157 \\
(0.250)\end{array}$ & $\begin{array}{c}0.855 \\
(0.214)\end{array}$ \\
\hline Lived apart from partner/spouse in last 12 months & $\begin{array}{l}1.987 * * * \\
(0.310)\end{array}$ & $\begin{array}{l}7.296^{* * *} \\
(2.263)\end{array}$ & $\begin{array}{c}2.425 * * * \dagger \\
(0.451)\end{array}$ & $\begin{array}{l}11.305^{* * *} \\
(5.098)\end{array}$ \\
\hline $\begin{array}{l}\text { Lived part from partner/spouse in last } 12 \\
\text { months*Number of formal loans }\end{array}$ & $\begin{array}{l}-1.145^{*} \\
(0.693)\end{array}$ & $\begin{array}{l}0.318 * \\
(0.221)\end{array}$ & $\begin{array}{l}-1.200 \dagger \\
(1.056)\end{array}$ & $\begin{array}{c}0.301 \\
(0.318)\end{array}$ \\
\hline Additional controls & & & & \\
\hline $\begin{array}{l}\text { Number of observations } \\
\text { Log-likelihood }\end{array}$ & & & & \\
\hline
\end{tabular}




\section{Appendices}

\section{Appendix 1}

Table 1A: Summary Statistics: Household and Partnership Characteristics

\begin{tabular}{|c|c|c|c|c|c|c|c|c|}
\hline \multirow[t]{2}{*}{ Variable } & \multicolumn{2}{|c|}{ Cohabit } & \multicolumn{2}{|c|}{ Separate - Cohabit } & \multicolumn{2}{|c|}{ Married } & \multicolumn{2}{|c|}{ Separate - Married } \\
\hline & Mean & Std. Dev. & Mean & Std. Dev. & Mean & Std. Dev. & Mean & Std. Dev. \\
\hline Length of relationship (years) & 5.73 & 5.2 & 3.94 & 4.08 & 14.7 & 7.49 & 11.68 & 6.57 \\
\hline $\begin{array}{l}\text { Difference in age (Respondent's } \\
\text { age - partner's age) }\end{array}$ & -2.51 & 5.89 & -292 & 6.12 & -238 & 4.49 & -223 & 515 \\
\hline $\begin{array}{l}\text { Partners have same level of } \\
\text { education }\end{array}$ & 0.34 & 0.47 & 0.33 & 0.47 & 0.37 & 0.48 & 0.31 & 0.46 \\
\hline Previously married & 0.07 & 0.25 & 0.06 & 0.23 & 0.03 & 0.18 & 0.06 & 0.24 \\
\hline Household characteristics: & 34.35 & 7.8 & 30.76 & 7.71 & 39.55 & 7.26 & 36.45 & 6.89 \\
\hline Respondent's age (years) & 36.85 & 8.55 & 33.68 & 8.55 & 41.93 & 7.86 & 38.68 & 7.51 \\
\hline Partner's age (years) & 1.74 & 0.9 & 1.88 & 1.04 & 1.72 & 0.92 & 2.01 & 0.94 \\
\hline Number of dependent children & 0.56 & 0.5 & 0.67 & 0.47 & 0.38 & 0.49 & 0.43 & 0.5 \\
\hline Higher degree/Degree - partner & 0.5 & 0.5 & 0.38 & 0.49 & 0.52 & 0.5 & 0.46 & 0.5 \\
\hline $\begin{array}{l}\text { Number of observations } \\
\text { (person-year) }\end{array}$ & & & & & 24 & & & \\
\hline
\end{tabular}




\section{Appendix 2}

Table 2A: Symmetry of Shocks

\begin{tabular}{|c|c|c|c|c|}
\hline \multirow[b]{2}{*}{ Variable } & \multicolumn{2}{|c|}{ Cohabiting } & \multicolumn{2}{|c|}{ Married } \\
\hline & Coefficient & $\begin{array}{c}\text { Hazard } \\
\text { Ratio }\end{array}$ & Coefficient & $\begin{array}{c}\text { Hazard } \\
\text { Ratio }\end{array}$ \\
\hline Increase in the number of formal loans outstanding & $\begin{array}{l}0.015 \\
(0.195)\end{array}$ & $\begin{array}{c}1.015 \\
(0.198)\end{array}$ & $\begin{array}{l}-0.016 \\
(0.187)\end{array}$ & $\begin{array}{c}0.985 \\
(0.184)\end{array}$ \\
\hline Decrease in the number of formal loans outstanding & $\begin{array}{l}0.295^{*} \\
(0.162)\end{array}$ & $\begin{array}{l}1.342^{*} \\
(0.217)\end{array}$ & $\begin{array}{c}0.228 \\
(0.154)\end{array}$ & $\begin{array}{c}1.256 \\
(0.193)\end{array}$ \\
\hline Increase in the number of debts in arrears & $\begin{array}{c}0.634 * * * \\
(0.171)\end{array}$ & $\begin{array}{c}1.886 * * * \\
(0.322)\end{array}$ & $\begin{array}{c}0.637 * * * \\
(0.210)\end{array}$ & $\begin{array}{l}1.891 * * * \\
(0.397)\end{array}$ \\
\hline Decrease in the number of debts in arrears & $\begin{array}{c}0.518 * * * \\
(0.165)\end{array}$ & $\begin{array}{c}1.678 * * * \\
(0.277)\end{array}$ & $\begin{array}{l}-0.141 \\
(0.249)\end{array}$ & $\begin{array}{c}0.868 \\
(0.216)\end{array}$ \\
\hline Respondent enters the labour market & $\begin{array}{c}0.258 \\
(0.228)\end{array}$ & $\begin{array}{c}1.294 \\
(0.295)\end{array}$ & $\begin{array}{l}-0.047 \\
(0.237)\end{array}$ & $\begin{array}{c}0.954 \\
(0.226)\end{array}$ \\
\hline Respondent leaves the labour market & $\begin{array}{c}0.035 \\
(0.248)\end{array}$ & $\begin{array}{c}1.036 \\
(0.257)\end{array}$ & $\begin{array}{c}0.344 \\
(0.279)\end{array}$ & $\begin{array}{c}1.411 \\
(0.393)\end{array}$ \\
\hline Partner enters employment from unemployment & $\begin{array}{c}0.053 \\
(0.403)\end{array}$ & $\begin{array}{c}1.055 \\
(0.425)\end{array}$ & $\begin{array}{l}0.809^{*} \\
(0.413)\end{array}$ & $\begin{array}{l}2.246^{*} \\
(0.928)\end{array}$ \\
\hline $\begin{array}{l}\text { Partner enters employment from out of the labour } \\
\text { force }\end{array}$ & $\begin{array}{c}0.379 \\
(0.435)\end{array}$ & $\begin{array}{c}1.461 \\
(0.635)\end{array}$ & $\begin{array}{l}0.711 * \\
(0.404)\end{array}$ & $\begin{array}{l}2.035 * \\
(0.823)\end{array}$ \\
\hline Partner leaves the labour market & $\begin{array}{l}-0.064 \\
(0.327)\end{array}$ & $\begin{array}{c}0.938 \\
(0.306)\end{array}$ & $\begin{array}{l}-0.340 \\
(0.357)\end{array}$ & $\begin{array}{c}0.712 \\
(0.254)\end{array}$ \\
\hline Constant & $\begin{array}{c}-1.119 * * \\
(0.483)\end{array}$ & $\begin{array}{l}0.326 * * \\
(0.158)\end{array}$ & $\begin{array}{c}-2.525 * * * \\
(0.889)\end{array}$ & $\begin{array}{l}0.080 * * * \\
(0.071)\end{array}$ \\
\hline $\begin{array}{l}\text { Number of observations } \\
\text { Log-likelihood }\end{array}$ & $\begin{array}{l}6,8 \\
-11\end{array}$ & & $\begin{array}{c}21, \\
-17\end{array}$ & \\
\hline
\end{tabular}




\section{Appendix 3: Determinants of Job Search}

As mentioned, the FACS asks our female respondents a series of questions on job search including whether they have been looking for paid work of 16 hours or more a week at any time during the past 12 months (Table 7). We use the responses to this question to estimate the determinants of job search for our married female respondents $\left(y_{i t}=1\right)$ using a latent variable model of the form:

$$
y_{i t}^{*}=z_{i t}^{\prime} \delta+\alpha_{i}+\varepsilon_{i t}
$$

where $y_{i t}^{*}$ is a continuous but unobserved propensity for job search, $z_{i t}$ is a vector of explanatory variables, $\alpha_{i}$ captures time invariant individual specific effects, and the error term, $\varepsilon_{i t}$ is assumed to have a logistic distribution. Chamberlain $(1980,1984)$ shows that such a fixed-effects logit model can be estimated by conditional maximum likelihood.

Table 3A illustrates the results for the fixed effect (conditional) logistic model for the probability of job search. The results show that the female respondent's decision to increase her labour supply appears to be strongly linked to a worsening financial situation in the home. 


\section{Table 3A: Conditional (Fixed Effects) Logit for the Determinants of Job Search}

\begin{tabular}{|l|c|}
\hline Variable & Coefficient \\
\hline We share and manage our finances jointly & 1.019 \\
Partner unemployed & $(0.077)$ \\
& $1.742 * *$ \\
Owner (=1 if owned outright) & $(0.380)$ \\
& 0.802 \\
Mortgage (=1 if has mortgage against property) & $(0.225)$ \\
& 0.817 \\
Saving (=1 if savings) & $(0.178)$ \\
& 1.025 \\
Loan (=1 if has a loan, 0 otherwise) & $(0.089)$ \\
& 1.072 \\
Number of debts in arrears & $(0.074)$ \\
& $1.121 *$ \\
& $(0.066)$ \\
\hline Number of observations & 7,243 \\
Log-likelihood & -2653 \\
\hline Notes: Standard errors in parentheses: $* * * \mathrm{p}<0.01, * * \mathrm{p}<0.05, * \mathrm{p}<0.1$ \\
\hline
\end{tabular}

We find that her search decision is partly linked to the male partner's employment status. In households where the partner becomes unemployed the female respondent is more likely to start to search for employment. Similarly, increased financial stress brought about by an increase in the number of debts the household cannot repay is also likely to trigger female job search. In contrast, variables that might depict deterioration in the stability of the partnership, such as changes to the system of money management are insignificant in this setting. 